Article

\title{
How to Transform Sustainable Energy Technology into a Unicorn Start-Up: Technology Review and Case Study
}

\author{
Dasheng Lee ${ }^{1, *}$ and Kuan-Chung Lin ${ }^{2}$ \\ 1 Department of Energy and Refrigerating Air-Conditioning Engineering, National Taipei University of \\ Technology, Taipei 10608, Taiwan \\ 2 Taiwan Shin Kong Global Venture Capital International, Taipei 10485, Taiwan; kuanchunglin@gmail.com \\ * Correspondence: f11167@ntut.edu.tw
}

Received: 10 March 2020; Accepted: 1 April 2020; Published: 9 April 2020

\begin{abstract}
Renewable and sustainable energy technologies must undergo commercialization before contributing to people's sustainable development. Among different approaches, commercialization to become unicorn start-ups has attracted considerable attention. Unicorn start-ups are companies achieving a valuation of over US $\$ 1$ billion before launching initial public offerings. Herein, a company adopting solid oxide fuel cells as its single product and becoming a unicorn start-up is considered the case company (Company B). Established in 2001, Company B accumulated US\$825.7 million of actual funding and a peak valuation of US $\$ 2.9$ billion before being publicly listed. After being listed in July 2018, Company B achieved unicorn start-up status. Searching ScienceDirect Online and the IEEE/IET Electronic Library, this. study collects reviews of fuel cell technology development trends. From CB insights, the study collects the timing and amount of funding received by fuel cell-related unicorn start-ups worldwide. The Derwent Innovation (DI) tool is employed to analyze the status of fuel cell-related patent applications of these unicorn start-ups. This study integrates technology review, business status, and patent application data for analysis. Unlike previous technology reviews focusing on researches and developments, this study emphasizes the analysis of intellectual-property-based (IP-based) commercialization strategies. Specifically, it analyzes key factors explaining how a company producing solid oxide fuel cells could transform into a unicorn start-up. These factors are compiled into a ladder framework to provide a reference. Five quantitative indices are promoted. From the managerial point of view, this framework provides an executable guideline for effectively transforming sustainable energy technology into a high-valuation unicorn start-up.
\end{abstract}

Keywords: fuel cell; unicorn start-up; CB insights; Derwent Innovation (DI) tool; intellectualproperty-based (IP-based) commercialization strategy; ladder framework for commercialization

\section{Introduction}

Commercialization is the process of introducing a product or sales model into the market [1]. It is the only way to make renewable and sustainable energy technologies (RETs and SETs) available to people. Successful commercialization has many different approaches such as the point sales and marketing in a single location, in one or several regions, or into an international market. Among these approaches, commercialization to become unicorn start-ups has attracted considerable attention. It enables an effective and fast way for adoption of technology products throughout the world. In this study, how to transform SET into a unicorn start-up was investigated. The purpose of this study aims to develop a quantitative methodology for incubation of a unicorn start-up. Key research points are illustrated as follows. 
Firstly, research foundation, literature survey and data collection are reported in Section 2. There are three sections including:

- Commercialization of renewable and sustainable technologies

- Unicorn start-up definition and status

- Technology review of fuel cells

Then the study case-a fuel cell manufacturing company listed as a unicorn start-up is introduced in Section 3. There are two sections including:

- SOFC commercialization by the case company

- Competitors

Section 4 describes the methodology and research settings. There are five sections including:

- Features of unicorn start-ups

- Patent analytics

- Landscape drawing

- Quantitative indices

- Ladder framework for commercialization

Section 5 illustrates quantitative indices and methodologies to incubate a unicorn start-up related to SET. The managerial and academic implications of the results of this research are discussed in details. At last, Section 6 makes conclusions.

\section{Fundamental Analysis}

\subsection{Commercialization of Renewable and Sustainable Technologies}

Due to the complexity of the business environment, the commercialization of renewable and sustainable technologies has always been a challenge. A study published in 2010 [2] analyzed progress in the commercialization of sustainable energy technologies (SETs) in India, including solar water heating, solar electricity, wind energy, small hydro, biomass cogeneration, and energy waste. The study results indicated that commercialization and technology diffusion still require financial assistance, government subsidies, or soft loans. The study proposed that the tapped and potential capacities are $1.54 \%$ and $17.36 \%$, respectively. This indicates that SETs have a very low level of commercialization and thus necessitates the promotion of innovative financial mechanisms, marketing mechanisms, incentive schemes, and regulatory polices to accelerate the commercialization of such technologies. However, the study further revealed that although government-driven projects with one-time demonstrations cannot effectively drive SET popularization, central governments, nongovernmental organizations, international agencies, and community groups must participate in and fund (e.g., through subsidies or loans) the development of SETs in order to guide innovative mechanisms that engender successful SET commercialization.

Another study published in 2017 [3] proposed a ladder building approach for the commercialization of renewable energy technologies (RETs). The study analyzed RET development in Finland and investigated the following two questions: "What are the key factors that influence RET commercialization in Finland?" and "How do technological, regulatory, and market-related factors affect the widespread adoption of RETs in Finland?" The study results revealed that factors influencing RET commercialization include market dynamics, strong research and development (R\&D) infrastructure, technological know-how, environmental awareness, and supportive public policies. Successful commercialization depends on numerous factors, and expecting any single one of these to produce success is misguided. In addition, Finland's technological excellence, energy security concerns, sizeable renewable energy resources, $R \& D$ culture, and emerging demand for clean energy solutions worldwide render the clean-tech sector an obvious choice. The government has stated its interest in promoting the 
sector and making it the engine of the economy. On the basis of the findings, the study presented a ladder framework for the commercialization of RETs in Finland.

The ladder framework proposed in the aforementioned study is a valuable research concept. However, the scope of the mentioned study was limited to Finland, whose market dynamics, technology development, and business environment differ from those of other countries. Therefore, the study's findings may not be generalizable in the broader context and to other countries in the world. Furthermore, the study proposed environmental awareness as the main willingness-to-pay factor and simplified the problem of price differences by proposing that government subsidies be provided to compensate for price differences. The study provided no suggestions for RETs to accommodate actual market mechanisms.

The present study analyzes international commercialization and creates actual scenarios of market mechanisms to a ladder framework for the transformation of SETs and RETs into unicorn start-ups. Furthermore, the researchers refer to a previous study on new technology-based ventures that was published in 2017 [4]. The study adopted commercialization strategies based on intellectual property (IP) to analyze start-up development, particularly the development of globalized marketing. Subsequently, worldwide patents related to FC will be surveyed in this study. It is important to fill the gap between technology development and product commercialization. Except for patent analytics, the present study also integrates the methodologies of the aforementioned study and the ladder building approach for RETs or SETs [3] to reveal crucial factors for business development, and it constructs a ladder framework for the commercialization of technology development into a unicorn start-up. The academic and managerial implications will be discussed in the Results and Discussions section.

\subsection{Unicorn Start-up Definition and Status}

Unicorn start-ups are privately held start-up companies valued at over US\$1 billion. The term was coined in 2013 by venture capitalist Aileen Lee, choosing the mythical animal to represent the statistical rarity of such successful ventures. At the time of writing (end of 2019 2020), only 391 start-up companies worldwide are listed as unicorn start-ups, according to the CB insights database [5] However, unicorn start-up companies account for a total business valuation of US\$1.210 billion.

A business valuation is made by calculating a start-up company's acquired investment capital and the proportion of stocks in the investment capital. The CB insights database comprises fundraising records of start-up companies from numerous countries, including the United States, China, India, South Korea, the United Kingdom, Israel, Indonesia, Sweden, France, Hong Kong, Portugal, Australia, Belgium, Germany, Singapore, Switzerland, and 11 other countries. This study used the amount and timing of investments into start-up companies from each country to perform company valuations. If a company's value surpasses US $\$ 1$ billion, the company is added to the unicorn list.

$\mathrm{CB}$ insights classifies unicorn start-ups into the following 13 business categories: artificial intelligence; auto and transportation; cybersecurity; consumer and retail; data management and analytics; e-commerce and direct-to-customer; education tech; Fintech; hardware; health; Internet services and software; supply chain, logistics, and delivery; travel; and others. This paper discusses RET- and SET-related commercialization; RETs and SETs belong to the 'others' category and are rare. Specifically, this study selects an SET-related unicorn start-up selling fuel cell products as the study case (denoted as Company B for research ethic concerns) and compares it with unicorn start-ups worldwide belonging to other commercial categories by using quantitative data. In particular, the study analyzes information on international business and fundraising programs to construct a ladder framework for unicorn start-ups.

\subsection{Technology Review of Fuel Cells}

Among SETs, fuel cell development is a major technology trend. To obtain relevant publications regarding fuel cells, this study searches the ScienceDirect (SDOL) and IEEE/IET Library (IEL) databases 
using the keyword 'fuel cell'. Thus, 336,364 and 10,210 articles were retrieved from SDOL and IEL, respectively. The PRISMA method was employed to screen for research and review articles with practical commercialization results to establish the technology development history. The study comprehensively compares the commercialization process of Company B on the basis of fuel cell technology development trends.

Alkaline fuel cells (AFCs) have been used since the mid-1960s. They have no commercialized applications but were used in NASA's Apollo and Space Shuttle programs [6]. AFCs can achieve power generation efficiencies of up to $70 \%$. Their operating temperature varies between $150{ }^{\circ} \mathrm{C}$ and $200{ }^{\circ} \mathrm{C}$. Generators using AFCs typically have a power range of $300 \mathrm{~W}$ to $5 \mathrm{~kW}$. However, high-efficiency AFC systems have short operating lives because they use a liquid solution of potassium hydroxide as an electrolyte, which is highly corrosive and thus erodes machine parts. Therefore, AFCs cannot serve as a commercialized product and are only viable for applications that do not require long operating lives, such as space missions.

In 1988, Westinghouse Electric Corporation published a paper on SOFC systems and a 24-cell generator prototype [7]. According to this publication, SOFCs-pioneered by Westinghouse in the 1960s-apply stabilized zirconia as an electrolyte; stabilized zirconia can operate as a solid electrolyte at elevated temperatures. The 24-cell SOFC generator prototype was designed, fabricated, and tested. The generator contained three cells in parallel and eight in series. These cells operated at approximately $1000^{\circ} \mathrm{C}$. At a design current density of $250 \mathrm{~mA} / \mathrm{cm}^{2}$, a power of $284 \mathrm{~W}$ and $45 \%$ efficiency were achieved. After approximately $500 \mathrm{~h}$ of testing, the performance was stable. Commercial products were expected to be offered by the early 1990s. However, Westinghouse experienced a business downturn in the 1990s. In 1997, the company's fuel cell department was acquired by the German company Siemens AG. Despite its unsuccessful business development, Westinghouse was the most active company to invest in SOFC development. In 1968, the company filed a patent application for the aforementioned key component of SOFCs: zirconium oxide electrode doped in or on an oxide cathode. From 1960 to 1990, Westinghouse led the development of SOFC technology and filed the key patent application for constructing power generators.

In 1992, Japan held a seminar involving 19 participating countries [8]. During this seminar, Mr. Mayfield from the US Department of Energy (DOE) stated that the United States had decided to concentrate on funding molten carbonate fuel cells (MCFCs) and SOFCs-committing approximately US $\$ 30$ million and US\$20 million, respectively, for these causes-and considered the near-term commercialization of phosphoric acid fuel cells (PAFCs). The key report of the seminar involved the experiences of a commercialized power plant that adopted SOFCs. Mr. Yokota from Tokyo Electric provided a summary of his operational experiences with an 11-MW Goi power plant. Construction commenced in November 1990, and rated power was achieved in April 1991. By August 1992, $10,200 \mathrm{MWh}$ had been generated with an efficiency of $41 \%$.

A review paper on fuel cell status published in 1994 [9] explained that the development of fuel cells in the 1990s primarily involved three directions: SOFCs, MCFCs, and PAFCs. Among these developmental directions, MCFC-related R\&D is crucial (particularly the development of MCFCs with internal reforming) and can solve technical issues pertaining to complex piping in fuel cells for fuel preparation. A review of commercial development trends indicates that by mid-1994, the United States had exported approximately thirty-three 300-kW PAFC plants, twenty 675-kW PAFC stacks, two 25-kW SOFC modules, and one MCFC system. PAFCs were successfully developed in the 1990s, surpassing the development of SOFCs. This is because the operating temperature of PAFCs is the range of $180^{\circ} \mathrm{C}-200^{\circ} \mathrm{C}$, whereas that of SOFCs is $1000^{\circ} \mathrm{C}$. Hence, the lower operating temperature of PAFCs affords greater reliability, which is a major factor influencing the commercialization of a power generation system. However, PAFCs exhibit lower power generation efficiency. PAFCs typically have a peak power generation efficiency of approximately $40 \%$, compared with the $45 \%$ demonstrated by SOFCs commercialized in 1998. Under off-peak operating conditions, the power generation efficiency of PAFCs declines considerably. 
Apart from reviewing the development directions and commercial status of fuel cells, the aforementioned review paper [9] discussed the intense interest in fuel cells in Japan, a country with strict environmental regulations and high fuel prices. The current study's investigation of the commercial status of fuel cells indicates that Japan produced substantial research on such cells in the 1990s; by 2019, Japan had received the highest number of fuel cell research patents in the world.

A 1996 review of fuel cell status [10] proposed that proton exchange membrane fuel cells (PEMFCs) constitute the fourth R\&D direction regarding fuel cells; the first three R\&D directions are SOFCs, MCFCs, and PAFCs. The review revealed that the worldwide commercialization of fuel cells had begun in 1996 and that 200 fuel cell units were operational in 15 countries during that period. In addition, the review reported the following four fuel cell systems as prominent systems: PEMFC (Ballard Power Systems, Vancouver, B.C., Canada), PAFC (ONSI Corporation, South Windsor, CT, USA), MCFC (Energy Research, Inc., Danbury, CT and M-C Power Corp., Burr Ridge, IL, USA), and SOFC (Westinghouse Corporation, Pittsburgh, PA, USA). Notably, Ballard Power Systems provided 10-250-kW PEM plants in the 1990s; therefore, it can serve as a comparison for Company B in this study and can be denoted as Company Ba. However, Company B had yet to be established in 1996.

According to the 1996 review [10], PEMFCs, PAFCs, MCFCs, and SOFCs have operating temperatures of $80^{\circ} \mathrm{C}, 200^{\circ} \mathrm{C}, 650^{\circ} \mathrm{C}$, and $1000^{\circ} \mathrm{C}$, respectively. This demonstrates that the development trend of fuel cell technology is towards lower operating temperatures. Apart from their lower operating temperatures, PEMFCs exhibit rapid start-up capabilities. This technological advantage is suitable for vehicle applications. This prompted the U.S. Big Three automakers, Mercedes-Benz, and Honda Motors to cooperate with Company Ba in expanding fuel cell application to various fields.

A 1997 study compiled information on five fuel cell systems, namely AFCs, PAFCs, PEMFCs, SOFCs, and MCFCs; subsequently, the study proposed a sixth technology: direct methanol fuel cells (DMFCs) [11]. The advantages of DMFCs are that they can directly generate power from methane, have simple storage requirements (unlike hydrogen), and are simple to fabricate and transport. However, DMFCs are associated with greater contamination problems compared with other fuel cells, thus impairing their effective commercialization. Furthermore, the review estimated the capital costs required for constructing power systems of different fuel cells. The 1997 study also reported that the capital cost required for constructing a PAFC, the most commonly constructed power system in the era, was approximately US $\$ 2000$ per $5000 \mathrm{~kW}$. The report predicted that in 2000, a 200-kW power generation system with a PAFC core would save US $\$ 1500$ for every $2000 \mathrm{~kW}$ generated. If MCFC or SOFC systems achieve a $60 \%-75 \%$ power generation rate, greatly exceeding the $40 \%$ power generation rate of PAFC systems, the estimated short-term capital cost would be US $\$ 1600$ to US\$1800. In the long term, the estimated capital cost would be US\$650 to US\$850 for every $1 \mathrm{~kW}$. Notably, the study indicated that PEMFC technology was selected by the US DOE for mid-term introduction of fuel cells in light-duty applications (National Programme Plan for Fuel Cell in Transport). DOE studies have indicated that prices in the range of US\$50/kW should be possible for mass production.

Compared with the estimated capital costs proposed in the aforementioned studies, the unicorn start-ups investigated in this study released a 1-kW home-sized energy server priced at US $\$ 3000$ in 2010, indicating a capital cost of up to US\$3000/ $/ \mathrm{kW}$. Considering changes in the US consumer price index between 2000 and 2010, the actual capital cost of SOFCs is US\$2180/kW. This statistic indicates that the cost of commercializing fuel cells is considerably greater than that predicted by the aforementioned studies.

In 2000, the Science and Technology Centre of Siemens Westinghouse Power Corporation published an article: Advances in SOFC Technology [12]. The company combined an SOFC with a micro-turbine generator to create a 250-kW hybrid pressurized SOFC-GT power generation system that can achieve a $57 \%$ power generation rate. Theoretically, the system can achieve a $70 \%$ power generation rate, thereby meeting the expected power generation rate proposed by the 1997 review [11].

Numerous scholars have reviewed SOFC technology development between 2001 and 2017. Topics considered in such reviews are outlined as follows: status and design selection of anode materials for 
SOFCs [13-17]; sealants for SOFCs [18]; vacuum deposition methods for SOFCs [19]; optimization of set-up and operating conditions for single-chamber SOFCs [20]; numerical and mathematical modelling of SOFCs [21-26]; Ni-YSZ cermet anode materials and alternative materials [27]; requirements of power electronics in SOFC systems [28]; power generation by SOFCs [29,30], [31]; mathematical analysis of SOFCs [32]; micro-electro-mechanical system fabrication, machining techniques, and electrospinning for SOFCs [32,33]; nanostructured anodes for SOFCs [34]; glass-based seals for SOFCs [35]; integration strategies for SOFCs including pressurized SOFC + Brayton cycle, non-pressurized SOFC + Brayton cycle, pressurized SOFC + Brayton cycle + air reheating, SOFC + PEMFC, SOFC + absorption refrigeration cycle, and SOFC + thermos-photovoltaic power generation [36]; metal-supported SOFC design [37]; SOFCs operating under electrolysis mode [24,38]; cathode-supported tubular SOFC designs [39]; SOFC control [40]; gas transport phenomena in porous electrodes of SOFCs [41]; chromium deposition and poisoning of SOFC cathodes [42]; and biomass as the energy source of ammonia-fed SOFCs [43,44]. The aforementioned studies involved review papers instead of individual research papers. Therefore, their conclusions were based on various research theories. Compiling and assess these reviews reveals a changing trend. Most studies conducted before 2000 have proposed novel types of fuel cells. After 2000, a substantial body of research has focused on mechanical design, electronic design, and SOFC material selection. In addition, research has proposed adopting numerical-modelling-optimized operating strategies to optimize and adjust established SOFC frameworks.

Company B was established in 2001, and by 2010, it released a commercialized SOFC-based 1-kW home-sized energy server [45]. During this period, numerous studies on SOFCs were published, thus considerably facilitating the commercialization process of such cells.

In addition to SOFCs, other fuel cell systems were massively produced after 2000. However, because R\&D processes for SOFCs occurred earlier, research on other types of fuel cells was published at later dates. Therefore, research on SOFC applications was published relatively earlier. For example, A Review of Fuel Cell Systems for Maritime Applications, published in 2016 [46], reported that between 1980 and 1998, PEMFC systems and hydrogen were used as the power source in submarine air-independent propulsion systems. From 1998 to 2004, an MCFC-PEMFC hybrid power application for naval ships was created. Between 2003 and 2013, an offshore supply vessel adopted MCFC and LNG as power sources. Between 2005 and 2008, a mega-yacht from the Fraunhofer Institute combined SOFC and gas turbines for power generation. Moreover, between 2008 and 2011, the boat BV employed a PEMFC as its power source. Between 2009 and 2016, an SOFC and diesel engines were employed for a multipurpose marine system. During the same period, a high-temperature PEMFC was being experimented for cruise ship applications. As mentioned, PEMFCs are characterized by rapid start-up and are suitable for maritime applications. This thus explains why they became the primary fuel cells in mobile vehicles. Studies have also tested the suitability of MCFCs and SOFCs in the aforementioned applications and compared their performance with that of PEMFCs. Notably, low-temperature fuel cells such as PEMFCs can achieve high electrical efficiencies if hydrogen is available as a logistic fuel. However, the efficiency is significantly reduced if hydrocarbon fuels are used; this is mostly due to the need to reform and clean these fuels and subsequent parasitic losses. Therefore, heavy-duty internal combustion engine generators are probably more efficient. High-temperature fuel cells such as SOFCs provide better integration with fuel-processing equipment and have higher tolerance levels for fuel impurities; in particular, when combined with gas turbines or reciprocating engines, SOFC systems can attain higher electrical efficiency levels than conventional generators can.

Studies on PEMFC enhancement are currently ongoing. Anion exchange membrane fuel cells (AEMFCs) are enhanced PEMFC models. Research on AEMFCs first appeared in 2000. A study [47] reported that AEMFCs exhibit improved performance and high stability in 2018. In 2019, numerous reviews of PEMFCs were published, including a review of PEMFC-based micro-combined heat and power systems [48], PEMFC applications for electric vehicles and energy management strategies [49,50], PEMFC poisoning by contaminants and impurities [51], mechanical compression effects and stress 
effects on PEMFCs [52,53], humidification strategy for PEMFCs [54], and design optimization for PEMFCs [55]. These reviews are similar to the 2000 reviews of SOFCs. The 2019 reviews of PEMFCs discussed the mechanical design, electric design, and material selection of PEMFCs. Compared with the SOFC reviews, the PEMFC reviews involved greater discussions of PEMFC applications and strategies for combining PEMFCs with heat and power systems. Furthermore, SOFCs were developed in the 1980s, whereas PEMFCs were developed between 1990 and 2000; hence, PEMFC reviews were mostly published later, from 2000 to 2019.

A 2019 review [56] examined 190 research publications on fuel cells integrated into electric grids and discussed the fuel cell-grid interface, interfacing components, and power quality problems. Moreover, the review categorized power ratings into low power (less than $10 \mathrm{~kW}$ ), medium power (between 10 and $100 \mathrm{~kW}$ ), and high power (more than $100 \mathrm{~kW}$ ), and described development trends and optimization strategies. Finally, the review discussed the practicability of fuel cells. The review paper indicates that among numerous fuel cells, only PEMFCs and SOFCs are suitable for connection with power grids. PEMFCs are suitable for small and moderate power loads between $10 \mathrm{~W}$ and $10 \mathrm{~kW}$ and exhibit the advantages of high power density and rapid response. SOFCs are suitable for moderate- and high-power loads from $10 \mathrm{~kW}$ to $10 \mathrm{MW}$ and exhibit the advantage of high conversion efficiency. Additionally, one review conducted energy and exergy analyses on various fuel cell types [57]. A theoretical analysis indicated that PEMFCs constitute a promising electrochemical energy conversion device for light-duty applications and have a maximum temperature of $90{ }^{\circ} \mathrm{C}$, thus rendering them suitable for use in applications such as automobiles, buildings, electronics, and rechargeable batteries. However, on the basis of pressure and voltage parameters, the energy and exergy analyses showed energy and exergy efficiencies of $47.6 \%$ and $50.4 \%$, respectively. SOFCs are promising and reliable devices with several advantages, including safety, high robustness against fuel contaminants, and suitability for high-temperature production. The efficiency can be increased to more than $50 \%$. If a PEMFC is combined with heat and power systems such as gas turbines, its efficiency can be up to $70 \%$.

Till 2020, major researches focused on solving practical engineering problems such as the cell size effect on the performance of MCFC [58]; different modification methods to improve performances of microbial FC [59]; and performance variation caused by manufacturing tolerances and defects [60]. Most researches are related manufacturing technology developments, that indicate FC becomes a mature SET product and has wide commercial applications.

The aforementioned reviews reveal the gap between FC technology developments and commercialization to become a unicorn start-up. In this study, IP-based commercialization strategy is proposed to fulfill the gap. Subsequently, worldwide patents related to FC are included for analysis. Before the adoption of IP-based strategy, the study case is firstly introduced. Secondly, methodology and research settings are reported.

\section{The Study Case}

\subsection{SOFC Commercialization by the Case Company}

Company B, established in 2001, officially released its SOFC product in 2010. According to the fuel cell development trend presented in the preceding section, considerable data on SOFCs have been published in this period. Such data are beneficial to the commercialization of SOFCs.

The roots of Company B can be traced back to its founder and initial team members, who developed a fuel cell for NASA capable of producing air and fuel from solar-cell-generated electricity [45]. The team had knowledge, expertise, and resources, which are fundamental to a successful start-up.

Even if a start-up team had experience, the selection of product development methods, which is the first step in development, is crucial. During the product development period between 2001 and 2010, technology review results indicated that PEMFCs exhibited more applications and were met with greater anticipation compared with SOFCs. Moreover, companies intending to develop SOFCs would 
face competition with the big company which held numerous IP rights regarding SOFCs and thus impeded start-up companies from developing relevant products. From the technology application perspective, SOFC systems require complex piping for fuel preparation. Studies have proposed adopting MCFCs with internal reforming to solve this problem. Despite the three aforementioned disadvantages, Company B still decided to commercialize SOFCs as its exclusive product, which was the turning point in its commercial development; therefore, it became a unicorn start-up.

According to CB insights, Company B received substantial funding in May 2002 (within 1 year after its establishment). This funding, referred to as A round funding, involved US $\$ 4.7$ million. In February 2003, Company B received US $\$ 12$ million. By the end of 2014, the company had accumulated US $\$ 825.7$ million worth of funding and received a valuation of US\$2.9 billion. Continual acquisition of venture capital for product development during the inception stage is crucial for companies that have yet to release products. In addition, a high business valuation based on funding is essential for unicorn start-ups.

After its public listing in 2018, Company B completed its unicorn start-up development process. Currently, Company B focuses on the development of SETs and produces only one SOFC product, which is the most representative SET commercialization case. Furthermore, Company B is publicly listed on the Nasdaq Stock Market, signifying that its product is accepted by the consumer market. When Company B submitted its initial public offering (IPO), Japan had replaced the United States as the country with the most fuel cell-related patents. The aforementioned technology reviews revealed that substantial PEMFC research data are available currently, with the Japanese company Honda releasing commercialized fuel cell vehicles [61]. Moreover, PEMFCs exhibit considerable application advantages in power generators that operate at less than $10 \mathrm{~kW}$. Accordingly, Company B released an energy server equipped with SOFCs to promote the core product values and establish new competitive strategies.

\subsection{Competitors}

Table 1 presents the comparison, along with a summary of the business status of the companies and the reason for selecting the companies for comparison.

Table 1. Study company and its competitors, which are all manufacturers of fuel cell products or fuel cell-based power systems.

\begin{tabular}{|c|c|c|}
\hline Case & Status & Why Listed for Comparison \\
\hline $\begin{array}{l}\text { Study case } \\
\text { Company B }\end{array}$ & $\begin{array}{l}\text { A unicorn start-up prominent in SET development and with } \\
\text { a single product: energy server comprising an SOFC. } \\
\text { Estimated } 2018 \text { revenue: US } \$ 742 \text { million [62]. }\end{array}$ & Main study object. \\
\hline $\begin{array}{l}\text { Main IP owner } \\
\text { Company To }\end{array}$ & $\begin{array}{l}\text { Large commercial group from Japan holding numerous fuel } \\
\text { cell-related IP rights. } \\
\text { Estimated } 2018 \text { revenue: US } \$ 272 \text { billion [63]. }\end{array}$ & $\begin{array}{l}\text { How the study case can avoid IP } \\
\text { portfolios established by a large } \\
\text { commercial group. }\end{array}$ \\
\hline $\begin{array}{l}\text { Business competitor } 1 \\
\text { Company PP }\end{array}$ & $\begin{array}{l}\text { Company producing fuel cell-based power generators. The } \\
\text { core business is almost the same as that of the study case. } \\
\text { Estimated } 2018 \text { revenue: US } \$ 175 \text { million [64]. }\end{array}$ & Main business competitor. \\
\hline $\begin{array}{l}\text { Business competitor } 2 \\
\text { Company Ba }\end{array}$ & $\begin{array}{l}\text { Fuel cell product development service company owning } \\
\text { automotive-related fuel cell IP rights and extension of } \\
\text { engineering service. } \\
\text { Estimated } 2018 \text { revenue: US\$96.6 million [65]. }\end{array}$ & $\begin{array}{l}\text { Business competitor prominent in } \\
\text { innovative applications of fuel cells. }\end{array}$ \\
\hline $\begin{array}{l}\text { Business competitor } 3 \\
\text { Company FE }\end{array}$ & $\begin{array}{l}\text { Company providing efficient and affordable fuel cell } \\
\text { solutions for energy supply, recovery, and storage. } \\
\text { Estimated } 2018 \text { revenue: US } \$ 52.5 \text { million [66]. }\end{array}$ & $\begin{array}{l}\text { IPO company that did not become a } \\
\text { unicorn start-up during its development } \\
\text { period and that provides a suitable } \\
\text { comparison for the study case. }\end{array}$ \\
\hline $\begin{array}{l}\text { Business competitor } 4 \\
\text { Company } \mathrm{Nu}\end{array}$ & $\begin{array}{l}\text { Company manufacturing fuel cell power and hydrogen } \\
\text { generation products. } \\
\text { Estimated } 2018 \text { revenue: US\$50 million [67]. }\end{array}$ & $\begin{array}{l}\text { Business competitor providing an } \\
\text { all-in-one fuel cell product. }\end{array}$ \\
\hline $\begin{array}{l}\text { Business competitor } 5 \\
\text { Company } \mathrm{H}\end{array}$ & $\begin{array}{l}\text { Company manufacturing hydrogen generation and fuel cell } \\
\text { products using PEMFCs. } \\
\text { Estimated } 2018 \text { revenue: US\$33.9 million [68]. }\end{array}$ & $\begin{array}{l}\text { IPO company but not a unicorn start-up } \\
\text { during the development period. }\end{array}$ \\
\hline $\begin{array}{l}\text { Business competitor } 6 \\
\text { Company JS }\end{array}$ & $\begin{array}{l}\text { Company providing affordable hydrogen power solutions } \\
\text { and discovered a way to safely extract hydrogen energy } \\
\text { from sea water. } \\
\text { Estimated } 2018 \text { revenue: US\$32 million [69]. }\end{array}$ & $\begin{array}{l}\text { Stealth company claiming hydrogen fuel } \\
\text { breakthrough since 2015. A developed } \\
\text { competitor of the study case. }\end{array}$ \\
\hline
\end{tabular}




\section{Methodology and Research Settings}

Unlike reviews discussing technology development trends or business research exclusively discussing commercial development strategies, the present study integrates technology development trends and commercial strategies with patent data for analysis.

The methodology of this study is based on that described in a previous study [4]. The study compares new technology-based ventures using IP-based, product-based, and hybrid (both productand IP-based) commercialization strategies on internationalization propensity and intensity. The study adopts 623 companies from 15 industry classifications as samples and analyzes the companies' international sales progress. The results reveal that new ventures using IP-based commercialization strategies exhibit higher internationalization intensity after foreign market entry than do those using hybrid and product-based strategies.

International marketing of products is an essential strategy for rapid commercial development. The results of previous research demonstrate that IP-based commercialization strategies constitute the most effective method of achieving foreign market entry and international sales. The results thus support the present study's use of IP to investigate the patent applications of Company B and competitors; thus, this study integrates technology review, case study, and IP data to analyze the development of SETs and discuss how to transform SET into a unicorn start-up.

The following sections explain the study methodology.

\subsection{Features of Unicorn Start-ups}

First, this study identifies features of unicorn start-ups based on IP commercialization strategy. The CB insights database is used to identify 391 start-up companies [4] belonging to 13 business categories from 11 countries. Although the selected start-ups differ greatly regarding their regional market environments and commercial fields, they exhibit IP-based commercialization and meet the aforementioned research settings. This study adopts IP applications to analyze the operational status of the 391 start-ups and conducts a cross-correlation analysis on the timing and amount of funding to identify features of unicorn start-ups.

The study categorizes the companies into successful and unsuccessful unicorn start-ups. The main features of successful unicorn start-ups include successful IPOs and constant fundraising growth. By contrast, unsuccessful unicorn start-ups exhaust their capital or fail to launch IPOs. On the basis of IP-based commercialization strategies, this study derives coefficients of the cross-correlation between IP applications and features, thus providing quantitative analysis results.

After analyzing the 391 start-up companies, this study explains the features of three unicorn start-ups with apparent differences from Company B. Table 2 presents the compared companies, their commercial fields, and the reasons for including them in the comparison.

Table 2. Study case and comparative unicorn start-ups in different commercial fields.

\begin{tabular}{ccc}
\hline Case & Commercial Field & Why Listed for Comparison \\
\hline $\begin{array}{c}\text { Study case } \\
\text { Company B }\end{array}$ & $\begin{array}{c}\text { Unicorn start-up prominent in SET development and } \\
\text { providing a single SOFC product. }\end{array}$ & Successful IPO in 2018. \\
\hline $\begin{array}{c}\text { Comparative unicorn 1 } \\
\text { Company M }\end{array}$ & $\begin{array}{c}\text { Company developing a lightweight, wearable device } \\
\text { that provides novel digital experiences [70]. }\end{array}$ & $\begin{array}{c}\text { Continuous funding from } \\
\text { worldwide venture capital groups. }\end{array}$ \\
\hline $\begin{array}{c}\text { Comparative unicorn 2 } \\
\text { Company J }\end{array}$ & $\begin{array}{c}\text { Company providing consumer technology and } \\
\text { wearable products [71]. }\end{array}$ & $\begin{array}{c}\text { Used to be a unicorn start-up but } \\
\text { exhausted all capital. }\end{array}$ \\
\hline $\begin{array}{c}\text { Comparative unicorn 3 } \\
\text { Company Y }\end{array}$ & $\begin{array}{c}\text { Powered by data and artificial intelligence, they } \\
\text { provide a platform for smart cities, smart finance, } \\
\text { smart retail, and more [72]. }\end{array}$ & $\begin{array}{c}\text { Failed to initiate/provide IPOs } \\
\text { until 2019. }\end{array}$ \\
\hline
\end{tabular}

\subsection{Patent Analytics}

IP-based commercialization strategies focus on achieving international sales through protection of patents. Therefore, the second step in the analysis of Company B is to adopt the Derwent Innovation 
(DI) tool to analyze worldwide patents related to fuel cells. From January 1980 to August 2019, 399,310 fuel cell-related patents exist worldwide. Furthermore, Company B applied for 1099 patents in 14 countries. Figure 1 displays the relevant information.

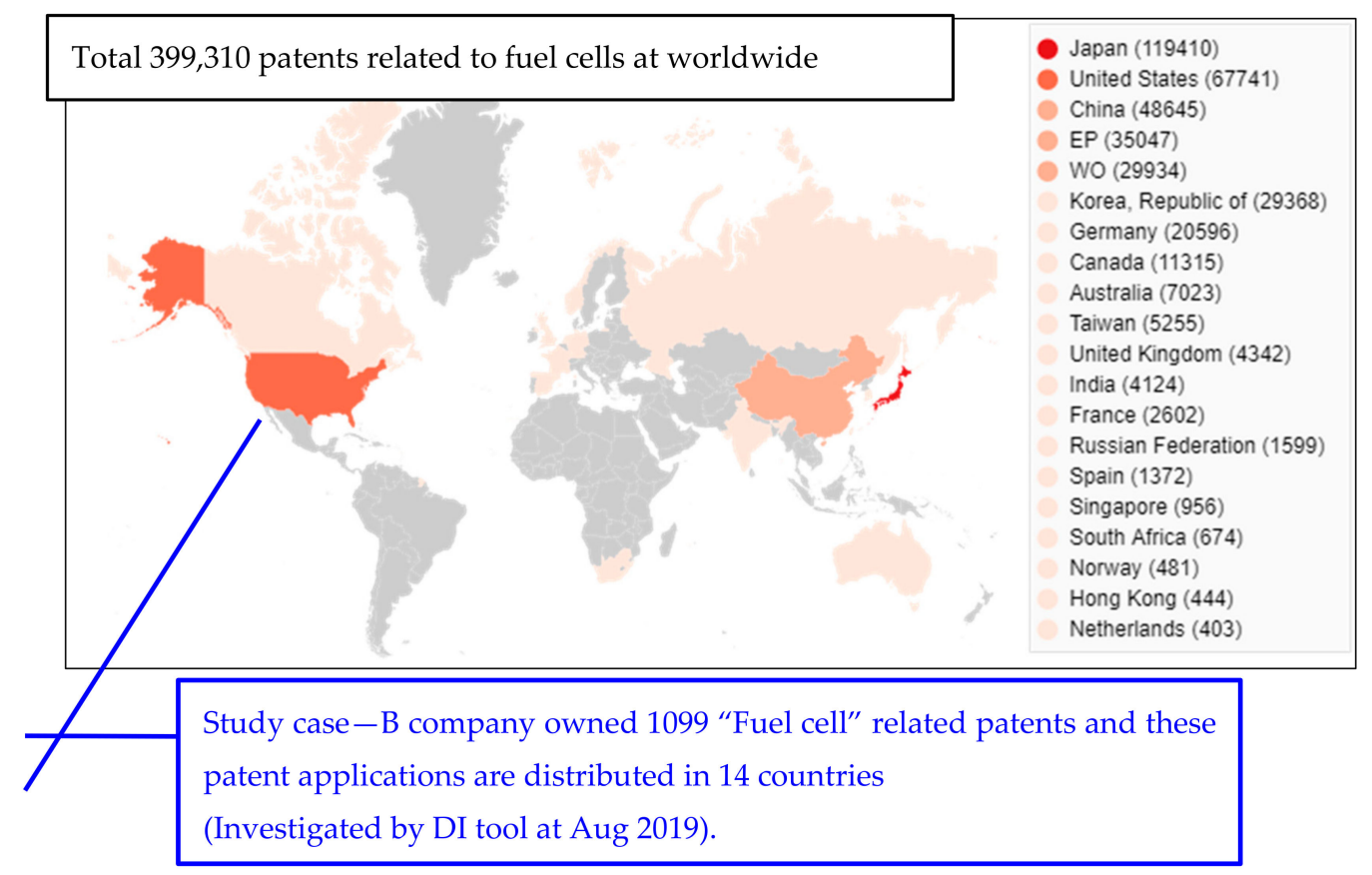

Figure 1. Worldwide patents related to fuel cells and patents owned by the study case.

The total 399,310 patents referred to in Figure 1 are summarized in Supplementary Materials. The grant number and brief description of each patents are listed for readers' quick check. In this study, a huge amount of patent data will be analyzed by a visual tool-ThemeScape provided by DI.

Patent analysis can assist in clarifying commercialization stages. This study adopts the changes in the number of applied patents and the number of companies applying patents to clarify the following four stages of commercialization: initial, developing, mature, and decay. On the basis of these four stages, this study can determine the number of applied patents, commercial development progress of Company B, and technology review results; thus, a thematic map of patent applications can be established and schematics can be developed to explain how Company B established core values during its commercial development.

\subsection{Landscape Drawing}

The third step of the research analysis is to compile technology review, case study, and IP information into a thematic map of patent applications based on the patent analysis results. The derived landscape is manually reviewed. The landscape contains the application dates of the 399,310 patents, conclusions from the 53 reviews, and Company B's business status and milestones. By classifying the information according to the initial, developmental, mature, and decay stages, the researchers review the method through which Company B established its patent portfolio in the competitive environment of international patent applications. Furthermore, this study conducts a quantitative analysis to compare the commercial milestones of Company B and the technology development trends reported by previous international research to reveal Company B's core values in commercial competition. These core values constitute the basis for further quantitative analysis. 


\subsection{Quantitative Indices}

Quantitative analysis is the fourth step of the analysis in this study. The ThemeScape mapping function of the DI tool is employed to review the competitive strategies of Company B against international competitors in patent applications. A company with the most fuel cell-related patents (To company) is used as the competitor for comparison with Company B. By adopting an actual business competitor for comparison, this study explains how to detect disadvantages through ThemeScape and construct IP portfolios on the basis of these disadvantages to protect commercial benefits.

This study proposes a patent power index (PPI), which is expressed as follows:

$$
P P I=e^{\frac{153}{\text { Word count of patent first claim }}}
$$

Through Equation (1), a company's total competitive strength associated with its patents can be computed. This study also proposes a patent portfolio competition index (PPCI), which is expressed as follows:

$$
P P C I=\frac{\text { Citation Patent Number }+ \text { PPI }}{\text { Years after company found }[\mathrm{min}=1]}
$$

The PPCI is used to compare the advantages of Company B with those of the business competitors listed in Table 1 in order to clarify the IP-based commercialization strategies of Company B, and identify the technological differences and thresholds between Company B and general commercial competitors. The greatest contribution of this study is its use of quantitative methods to determine technological differences in order to reveal the key factors to success in unicorn start-ups.

\subsection{Ladder Framework for Commercialization}

The final step in the analysis is to integrate the aforementioned results and ladder building approach [2] to reveal how Company B developed an SOFC and energy server using SETs and became a unicorn start-up valued at over US\$1 billion. Unlike previous qualitative studies, this study adopts quantitative indices (i.e., PPI and PPCI) and core values, technology, and business development status acquired from patent landscaping to develop a ladder framework for commercialization. The study findings can serve as a reference for converting SET into a unicorn start-up.

\section{Results and Discussion}

This study analyzes Company B to construct a ladder building approach that can serve as a reference for effectively transforming SET into useful approaches to establish high-valuation start-ups. This study selects unicorn start-ups listed in CB insights. The study then computes the number of patent applications filed and amount of funding received by the unicorn start-ups. The results indicate that for start-ups with continual funding and successful IPOs, the curve for the number of patent applications and that for the amount of funding are highly correlated. By contrast, for start-ups exhausting their capital or failing to launch IPOs, the two curves exhibit a low correlation. For the 391 unicorn start-ups, the cross-correlation coefficients between successful and unsuccessful start-ups are $0.97-0.99$ and $0.77-0.82$, respectively.

Figure 2 displays the data curves of Company B and three other unicorn start-ups with distinctive features. Figure 2a indicates that Company $\mathrm{M}$, which produces virtual reality products, constantly receives international funding. Figure $2 b$ displays the performance of Company $B$, which focuses on SETs and releases SOFC products to achieve high valuation; it conducted a successful IPO in 2018. In addition, Figure $2 c$ shows the fundraising process of Company J, which produces wearable devices. Despite successfully achieving high valuation through fundraising, Company J exhausted its capital and went out of business. Company Y - which primarily develops artificial intelligence technologies, including artificial intelligence platforms for security, finance, healthcare, and smart cities-has a high technological threshold. However, the company has yet to successfully issue an up-to-date IPO. Table 2 provides an overview of the four companies. 


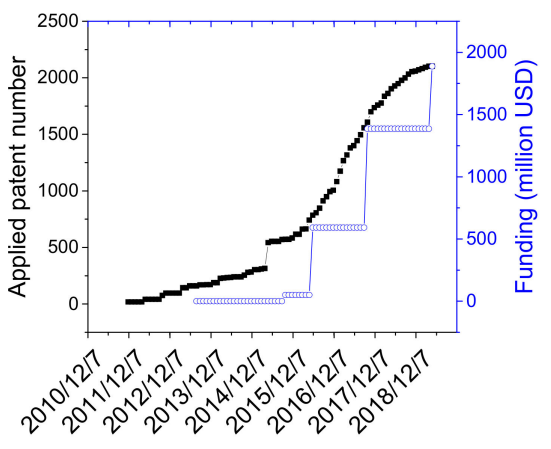

(a) Continuous fundraising unicorn.

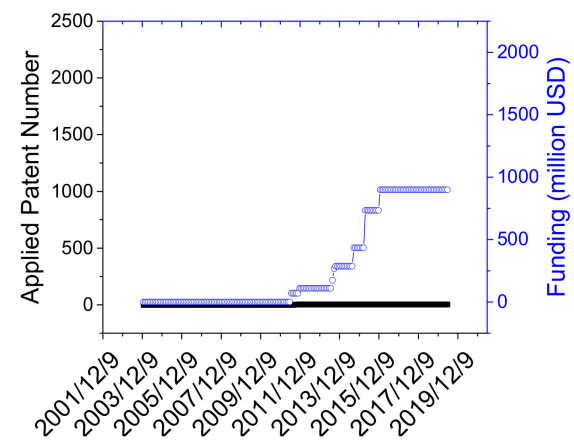

(c) Used to be a unicorn but burned out their capital.

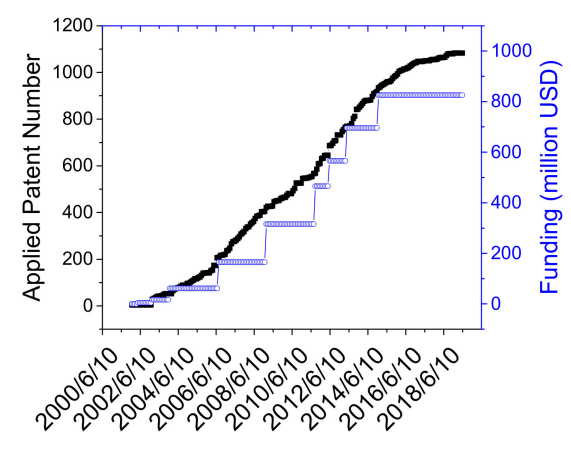

(b) Successful IPO unicorn

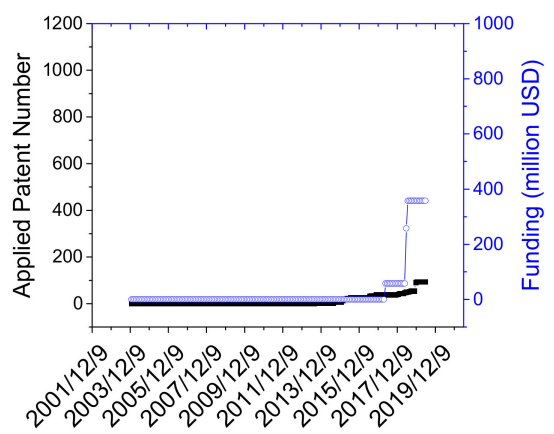

(d) Not IPO till now

Figure 2. Feature of unicorn start-ups is a high cross-correlation between number of applied patents and amount of funding. Applied patents of 391 unicorn start-ups are surveyed with the DI tool, and accumulated funding data are obtained from CB insights. Three unicorn start-ups that are comparative to the study case and their data curves are shown: (a) Company M, (b) Company B (study case), (c) Company J, and (d) Company Y. It's noted that black square dot-line indicates applied patent number and blue circular dot-line indicates accumulated funding.

Figure 2 presents a comparison of the statistics of the four unicorn start-ups, revealing that the number of patent applications increases with the amount of funding (correlation coefficient $>0.97$ ). To achieve business development, unicorn start-ups utilize substantial patent protection measures to constantly seek capital investment-it is crucial and the final ladder step for a unicorn start-up.

Commercialization to become a unicorn start-up requires the synchronous growth of patent numbers and funding. This study constructs a thematic map of patent applications to explain how Company B achieved these goals. The first step of constructing a thematic map of patent applications is to use the DI tool to analyze worldwide patents related to fuel cells and four different development stages. The results are illustrated in Figure 3. 


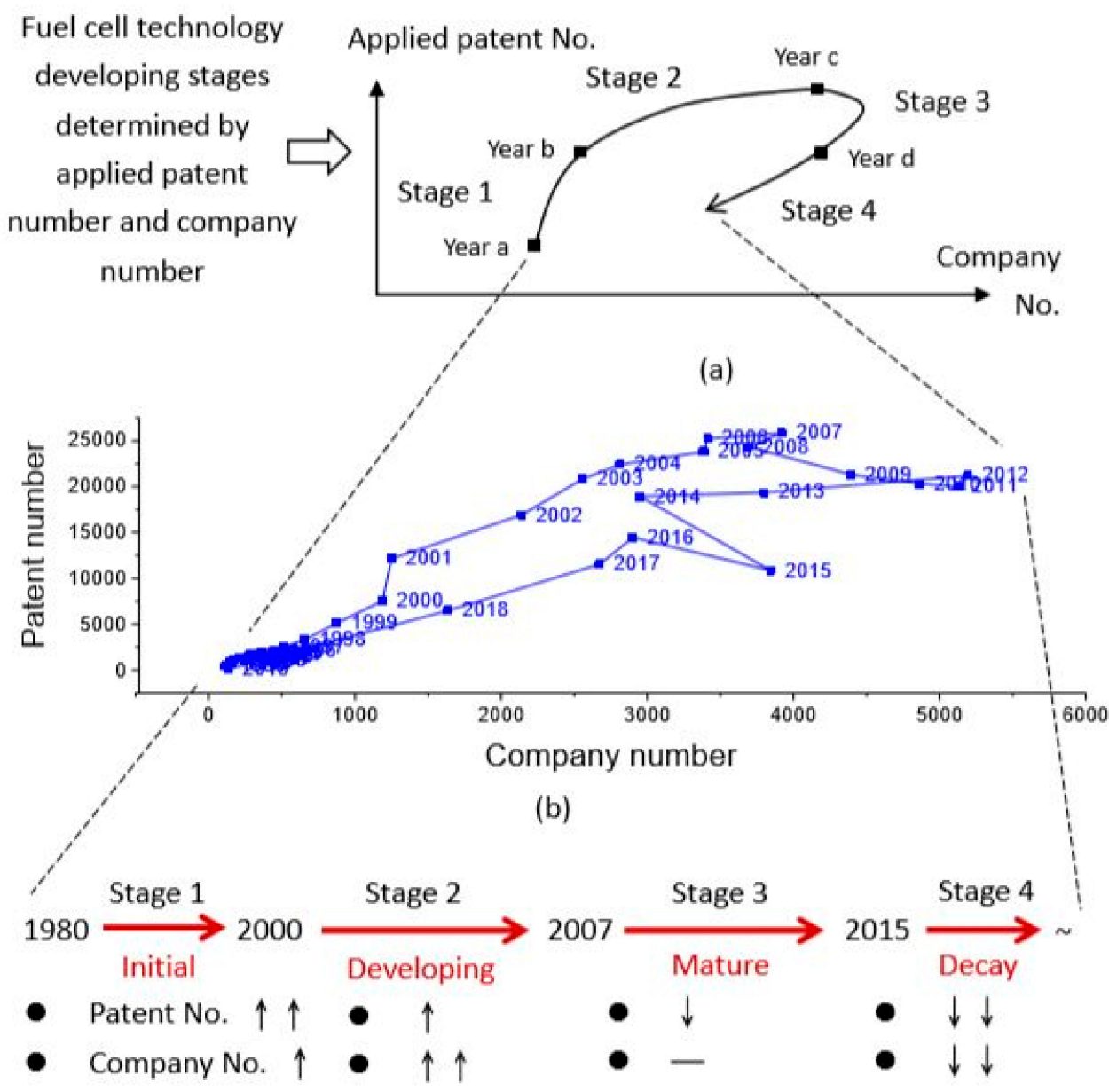

(c)

Figure 3. Worldwide patent analysis results: (a) criteria to determine the four development stages of fuel cell technology; (b) applied patent number and company number from 1980 to 2019; (c) status and period of initial, developing, mature, and decaying stages.

Figure 3a displays the analysis concept and the four stages, which are divided into the years $a, b, c$, and d. Figure $3 b$ shows the number of fuel cell-related patent applications and companies established each year (year is specified beside each data point), indicating a total of 399,310 patent applications worldwide. Figure $3 \mathrm{c}$ presents the categorization of the data from Figure $3 \mathrm{~b}$ into four stages. In the initial stage (i.e., 1980-2000), the technology is shown to be in early development. As this stage involves few patent holders, the number of applied patents exhibits a rapid growth trend. However, few companies in this period submitted patent applications compared with later stages. Between 2000 and 2007, the growth in the number of patent applications is shown to slow down, whereas the number of companies applying for patents is shown to increase rapidly. This rapid increase indicates the developing stage of fuel cell technology. After 2007, fuel cell technology reached a mature stage; hence, the number of submitted patent applications is shown to drop. However, the number of companies applying for patents is shown to be constant. After 2015, fuel cell technology reached the decay stage, with both the number of patent applications and the number of companies applying for patients decreasing.

Figure 4 depicts a thematic map of patent applications constructed according to the aforementioned four stages. 


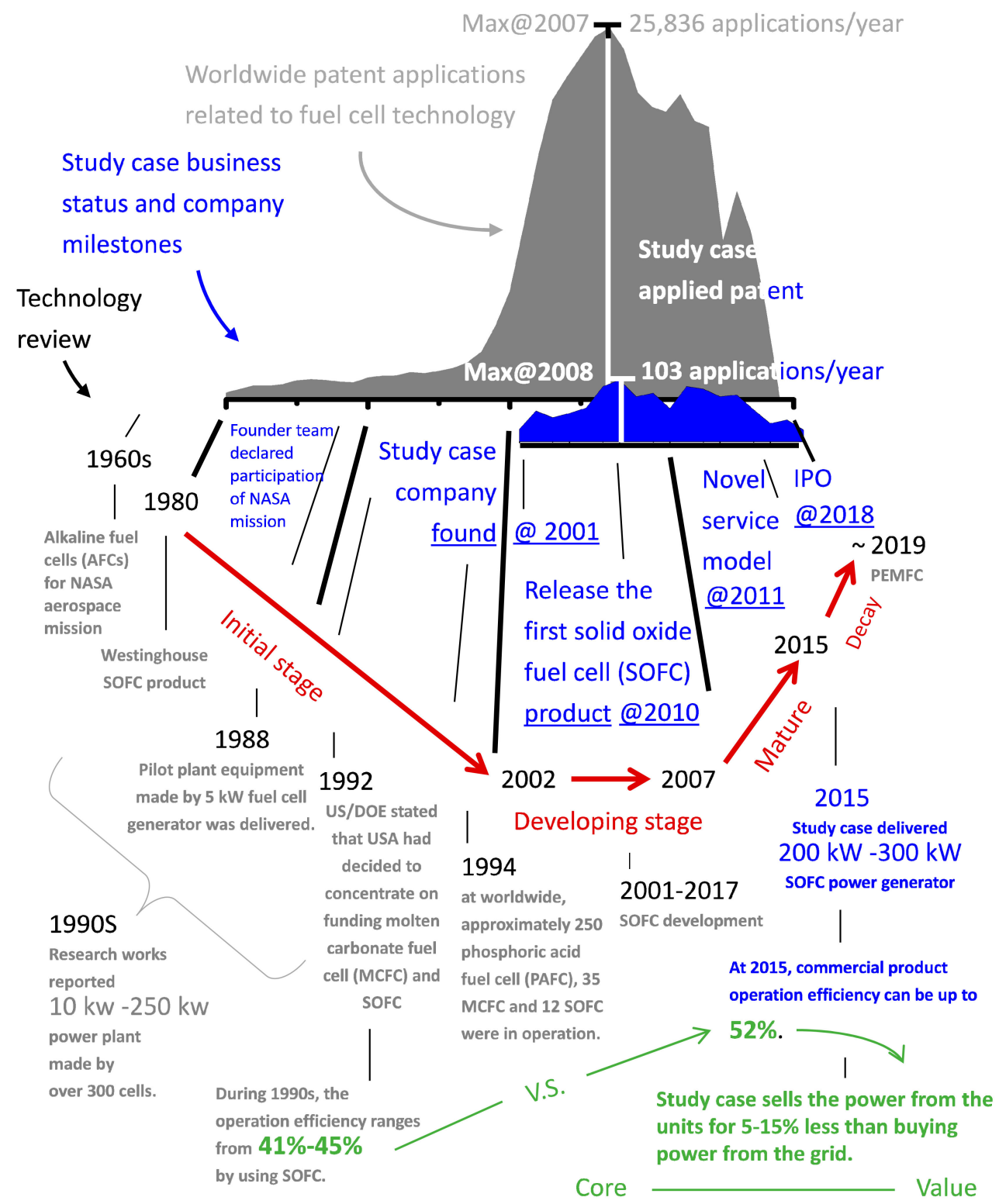

Figure 4. Landscape drawing comprising international patent applications, business status, company milestones, and fuel cell technology review results used to analyze the core value achieved by the study case.

This study constructs a thematic map of patent applications to integrate the historic number of submitted patent applications worldwide, number of patent applications submitted by Company $\mathrm{B}$, milestones of Company B, and results of fuel cell technology reviews. The development trend is divided into four stages, starting from 1980 (Figure 4). Each key research result is discussed according to the development stages.

Patent analysis is adopted to establish the four stages and observe when Company B competitively engaged in international patent application. Figure 4 reveals that Company B competitively engaged in international IPs at the development stage, a period characterized by a substantial growth in the numbers of patent applications and companies submitting patent applications, thereby posing competition difficulties for start-ups. The key factor enabling Company B to overcome the patent competition difficulties is its submission of SOFC-related patent applications. According to search results of patent data, Westinghouse Electric Corporation held 757 fuel cell-related patents before Company B was established. The patent protection encompassed SOFC systems, manufacturing 
methods, components, and functional materials. By 2001, however, most patents had expired, and the company faced unsuccessful fuel cell commercial development and merger threats. In addition, technology research in 2001 proposed that PAFCs or MCFCs could solve the application problems of SOFCs. The subsequently developed PEMFCs further reinforced the development trend of systems with relatively low operating temperatures. As Japan had the most fuel cell-related patent applications, numerous Japanese companies engaged in PEMFC development. This study also investigates the company with the most fuel cell-related patents. Apart from pursuing patent portfolios of membrane fuel cells, the company focused on applying for patents associated with hybrid electric vehicles. Due to the sufficient space for patents related to SOFC technology development, Company B could establish its own patent portfolio, enabling the company to develop strong IP strategies. Despite establishing its patent portfolio in the fuel cell development stage, Company B rapidly applied for substantial numbers of patents. In 2007, the number of fuel cell patents peaked. In 2008, Company B achieved its highest number of patent applications to date: 103. Although studies have not favored SOFCs and corporations with numerous SOFC patents faced operational difficulties, Company B focused exclusively on SOFC-related patent applications and acquired future development advantages. These are the key factors underlying Company B's business success. These factors are coincidental rather than being engendered by the company's operation. Therefore, these factors are not included in the established ladder.

The actual ladder for the promotion of Company B's initial commercial development is presented in Figure 4. Company B's founding team had experience in developing fuel cells for NASA's aerospace missions in the 1960s. During that period, the team mainly developed AFCs with high efficiency but short usage periods. After achieving the demands of the aerospace missions, the team leveraged the experience gained from the NASA tasks and selected SOFC technology for its core commercial development. In the 1990s, considerable data and numerous reviews supported Company B's product development. Although many modified models of fuel cell designs were developed, Company B remained focused exclusively on SOFC technology. The company achieved patent protection and released the developed product in 2010. Firms' knowledge, experiences, resources, and focus on product or service development are parts of the ladder proposed in this research.

Persistence is fundamental to the commercial success of corporations. Specifically, companies must persist in core commercial values to acquire true success. The green line in Figure 4 marks the core commercial value of Company $B$, which increased the power generation efficiency from $41 \%-45 \%$ to $52 \%$. By using these fuel cells to generate power with the company's energy servers, Company B could sell power at a price $5 \%-15 \%$ lower than the price of power-grid-supplied power. Therefore, the core value for successful commercial development is to promote renewable energy supply with lower prices.

Although international research has indicated that SOFCs have the potential of achieving a $70 \%$ power generation rate, Company B achieved successful commercialization, became a high-valuation unicorn, and successfully submitted its IPO by simply increasing the power generation rate to $53 \%$. Despite currently facing losses after filing for an IPO, Company B is an unquestionably successful example of how to transform SETs into unicorn start-ups. Therefore, this study does not further discuss why Company B did achieve further fuel cell operating efficiency or whether the $5 \%-15 \%$ price difference constituted the actual commercial purchase. Instead, this study discusses how Company B adopted IP commercialization strategies to achieve its core commercial values.

Further investigation reveals that Company B held 1099 patents. The following table classifies the patents according to the International Patent Classification system (technology categories).

The grey cells in Table 3 indicate that Company B focused on basic electrical-element-related technologies, particularly systems for the direct conversion of chemical energy into electrical energy. The patents pertained to novel processes for increasing power generation rates. Of Company B's patents, $77.7 \%$ were directly related to the company's core commercial values. Therefore, this study reveals that applying for patents to create core commercial value is a key ladder step to commercial success. 
Table 3. Study case patent statistics.

\begin{tabular}{|c|c|c|c|c|c|c|}
\hline Product & \multicolumn{3}{|c|}{ Technology Category } & \multirow{2}{*}{$\frac{\text { Quant./Ref }}{31}$} & \multirow{2}{*}{$\begin{array}{c}\text { Percent } \\
2.8 \%\end{array}$} & $\begin{array}{c}\text { Total } \\
\text { (Number) }\end{array}$ \\
\hline \multirow{28}{*}{$\begin{array}{c}\text { Fuel cell } \\
\text { and } \\
\text { energy } \\
\text { server }\end{array}$} & \multirow{10}{*}{$\begin{array}{l}\text { Performing } \\
\text { operation }\end{array}$} & Physical or chemical & Separation & & & \multirow{28}{*}{$\begin{array}{l}1099 \\
\text { patents; } \\
\text { Data } \\
\text { statistics up } \\
\text { to Sep, } \\
2019\end{array}$} \\
\hline & & processes & Catalysis or colloid chemistry & 3 & $0.27 \%$ & \\
\hline & & $\begin{array}{l}\text { Spraying or atomizing } \\
\text { in general }\end{array}$ & $\begin{array}{c}\text { Processes for applying liquids } \\
\text { or other fluent materials to } \\
\text { surfaces }\end{array}$ & 2 & $0.18 \%$ & \\
\hline & & Powder metallurgy & Working metallic powder & 5 & $0.46 \%$ & \\
\hline & & Machine tools & Combined operation & 2 & $0.18 \%$ & \\
\hline & & Working of plastics & Shaping or joining of plastics & 2 & $0.18 \%$ & \\
\hline & & Layered products & $\begin{array}{l}\text { Products built-up of strata of } \\
\text { flat or non-flat } \\
\end{array}$ & 1 & $0.09 \%$ & \\
\hline & & Vehicle & Propulsion unit in vehicle & 11 & $1 \%$ & \\
\hline & & Aircraft & $\begin{array}{c}\text { Equipment for fitting in or to } \\
\text { aircraft }\end{array}$ & 12 & $1.1 \%$ & \\
\hline & & $\begin{array}{c}\text { Handling thin } \\
\text { material }\end{array}$ & Machine, apparatus or devices & 2 & $0.18 \%$ & \\
\hline & \multirow{6}{*}{ Chemistry } & Inorganic chemistry & $\begin{array}{l}\text { Non-metallic elements and } \\
\text { compounds containing metals }\end{array}$ & 4 & $0.36 \%$ & \\
\hline & & Glass & $\begin{array}{l}\text { Manufacture or shaping of } \\
\text { glass and } \\
\text { chemical composition of glass }\end{array}$ & 6 & $0.55 \%$ & \\
\hline & & Cements & Ceramics & 8 & $0.64 \%$ & \\
\hline & & Petroleum & $\begin{array}{c}\text { Production of liquid } \\
\text { hydrocarbon mixtures }\end{array}$ & 2 & $0.18 \%$ & \\
\hline & & Metallurgy & $\begin{array}{l}\text { Refining of metals, alloys and } \\
\text { changing the physical } \\
\text { structure of metals and alloys }\end{array}$ & 11 & $1 \%$ & \\
\hline & & $\begin{array}{l}\text { Coating metallic } \\
\text { material }\end{array}$ & $\begin{array}{l}\text { Surface treatment by diffusion } \\
\text { into the surface }\end{array}$ & 2 & $0.18 \%$ & \\
\hline & & Combustion engines & $\begin{array}{c}\text { Controlling combustion } \\
\text { engines }\end{array}$ & 9 & $0.82 \%$ & \\
\hline & Mechanical & Engineering element & Joint and piping for pipes & 1 & $0.09 \%$ & \\
\hline & engineering & $\begin{array}{c}\text { Combustion } \\
\text { apparatus }\end{array}$ & Heating element & 1 & $0.09 \%$ & \\
\hline & & Heat exchanger & Multi-stream heat exchanger & 5 & $0.45 \%$ & \\
\hline & & Measuring and testing & $\begin{array}{c}\text { Measuring temperature, } \\
\text { electric and magnetic variables }\end{array}$ & 22 & $2 \%$ & \\
\hline & Physics & Control and regulate & $\begin{array}{c}\text { Control system for regulating } \\
\text { non-electric, electric and } \\
\text { magnetic variables }\end{array}$ & 5 & $0.45 \%$ & \\
\hline & & Computing & $\begin{array}{l}\text { Data and image processing } \\
\text { system }\end{array}$ & 16 & $1.5 \%$ & \\
\hline & & Basic electric elements & $\begin{array}{c}\text { Processes for the direct } \\
\text { conversion of chemical energy } \\
\text { into electrical energy }\end{array}$ & 854 & $77.7 \%$ & \\
\hline & & $\begin{array}{l}\text { Generation, } \\
\text { conversion or }\end{array}$ & $\begin{array}{l}\text { Systems for supplying, } \\
\text { distributing and storing } \\
\text { electric power }\end{array}$ & 56 & $5.1 \%$ & \\
\hline & Electricity & $\begin{array}{l}\text { distribution of electric } \\
\text { power }\end{array}$ & $\begin{array}{c}\text { Apparatus for conversion } \\
\text { between } \mathrm{AC} \text { and } \mathrm{AC}, \mathrm{AC} \text { and } \\
\mathrm{DC}, \mathrm{DC} \text { and } \mathrm{DC}\end{array}$ & 18 & $1.6 \%$ & \\
\hline & & $\begin{array}{c}\text { Electric } \\
\text { communication } \\
\text { technique } \\
\end{array}$ & Multiplex communication & 1 & $0.09 \%$ & \\
\hline & & Otherwise & $\begin{array}{c}\text { Manufacture of assembly of } \\
\text { electrical components }\end{array}$ & 7 & $0.5 \%$ & \\
\hline
\end{tabular}

Despite this ladder step, the main challenge for start-ups is to successfully apply for patents in global competitions. This study adopts the ThemeScape function of the DI tool to construct a figure that can serve as a reference for start-ups in identifying spaces to file patent applications.

On the basis of ThemeScape, the 399,310 patents associated with fuel cells worldwide can be visualized, as presented in Figure 5. This figure shows keywords for various patent technologies and the position of companies with the most fuel cell-related patents (dots in red). 


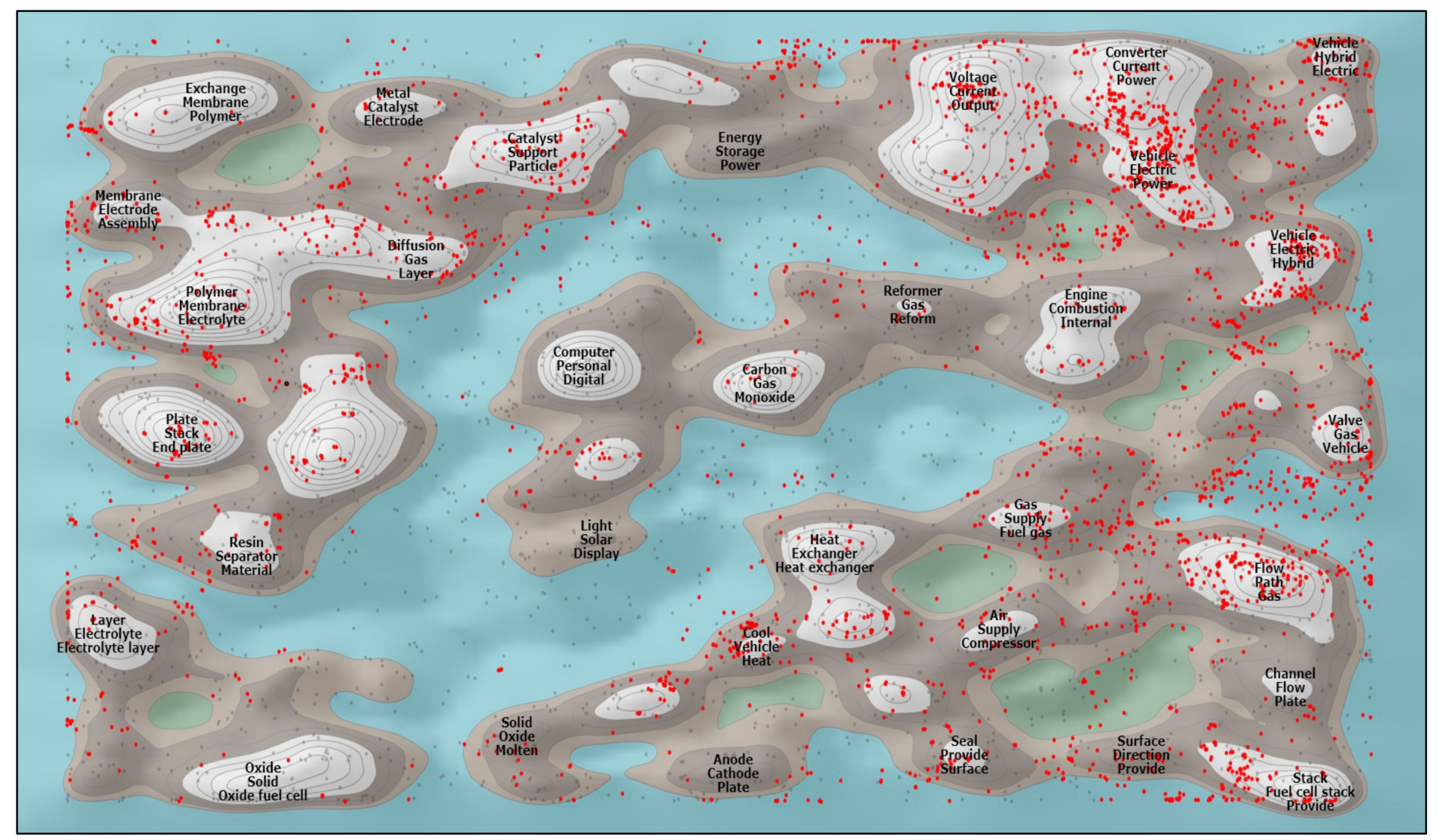

Figure 5. Competitor-To Company holds fuel cell-related patents (marked by red dots) and its distribution on thematic map of worldwide patent applications. 
As shown in Figure 5, competitor to study case, Company To, holds the most fuel cell-related patents at worldwide but does not occupy the SOFC category in the thematic map of patent applications with keywords of oxide solid/oxide fuel cell, thus enabling Company B to establish their patent protection.

Furthermore, Figure 6 displays the study case, Company B's patents, on the fuel cell-related thematic map of IPs. This figure reveals that the patent space in the dotted line areas on Figure 5 is occupied by Company B's patents. Company B is shown to establish comprehensive patent protection for SOFC category in the thematic map of patent applications with keywords of oxide solid/oxide fuel cell (marked within white dotted line and highlighted by comparing with Figure 5). In addition, Company B is shown to establish patent protection for stack design technology with keywords of stack/fuel cell stack provide (marked within black dotted line), which is crucial to improving SOFC operating efficiency.

Using ThemeScape, this study can effectively compare the case company with international competitors. Moreover, this study uses the openings in the landscape to establish a patent portfolio for worldwide competition. This patent portfolio serves as the fourth step of the ladder proposed in the study.

High patent value is the common threshold in determining whether to establish patent portfolios or whether to focus on applying for patents related to core values. This study investigates patents with strong claims and numerous citations recognized by patent engineers. After conducting analysis, this study proposes the PPI and PPCI as parameters to compute patent value. The study computes the indices of all Company B's patents and then compares them with those of the six business competitors in Table 1. The comparison reveals that Company B has much greater statistics. Figure 7 shows the PPCI comparison of Company B and six business competitors. 


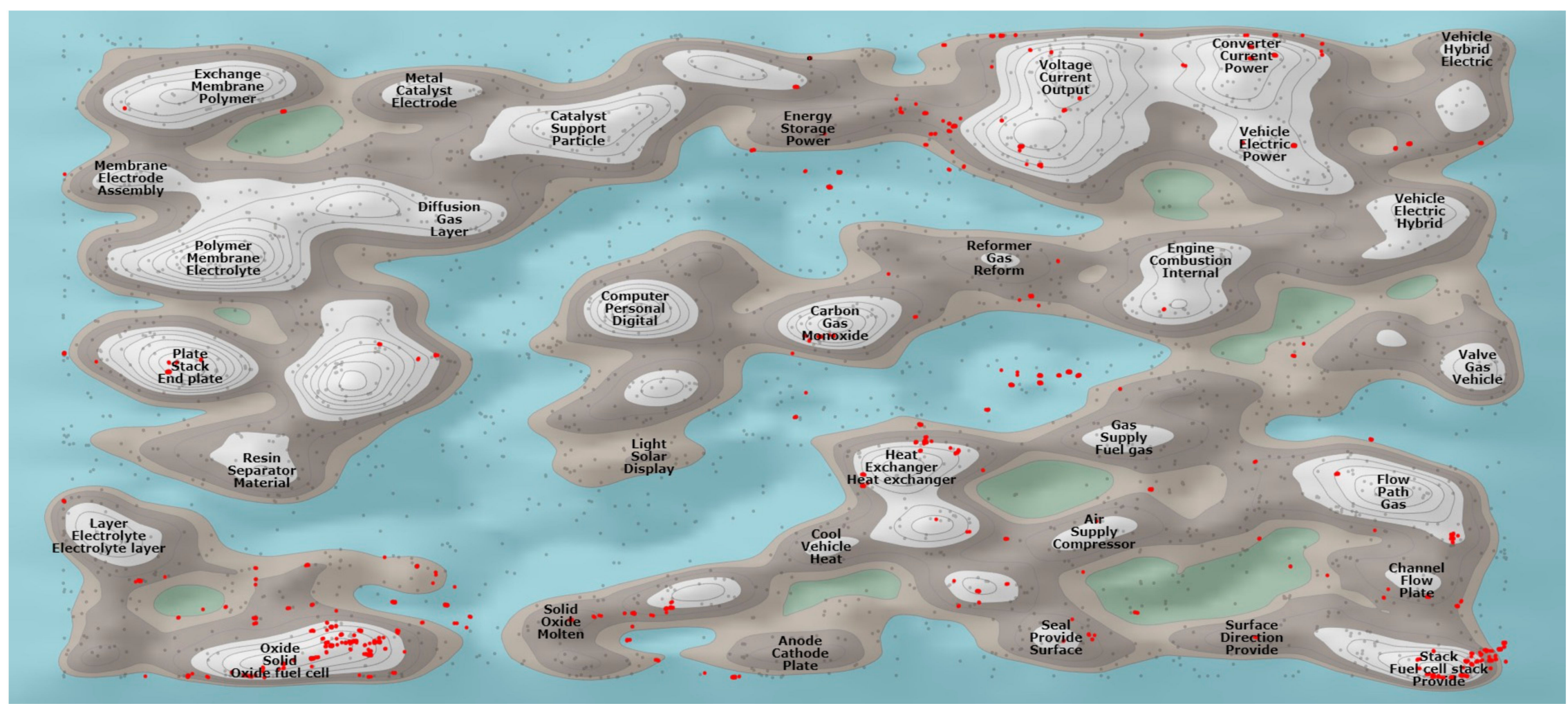

Figure 6. Study case-Company B built comprehensive patent protection (marked by red dots) for SOFC category in the thematic map of patent applications with keywords of oxide solid/oxide fuel cell (within white dotted line). In addition, Company B is shown to establish patent protection for stack design technology with keywords of stack/fuel cell stack (within black dotted line). 


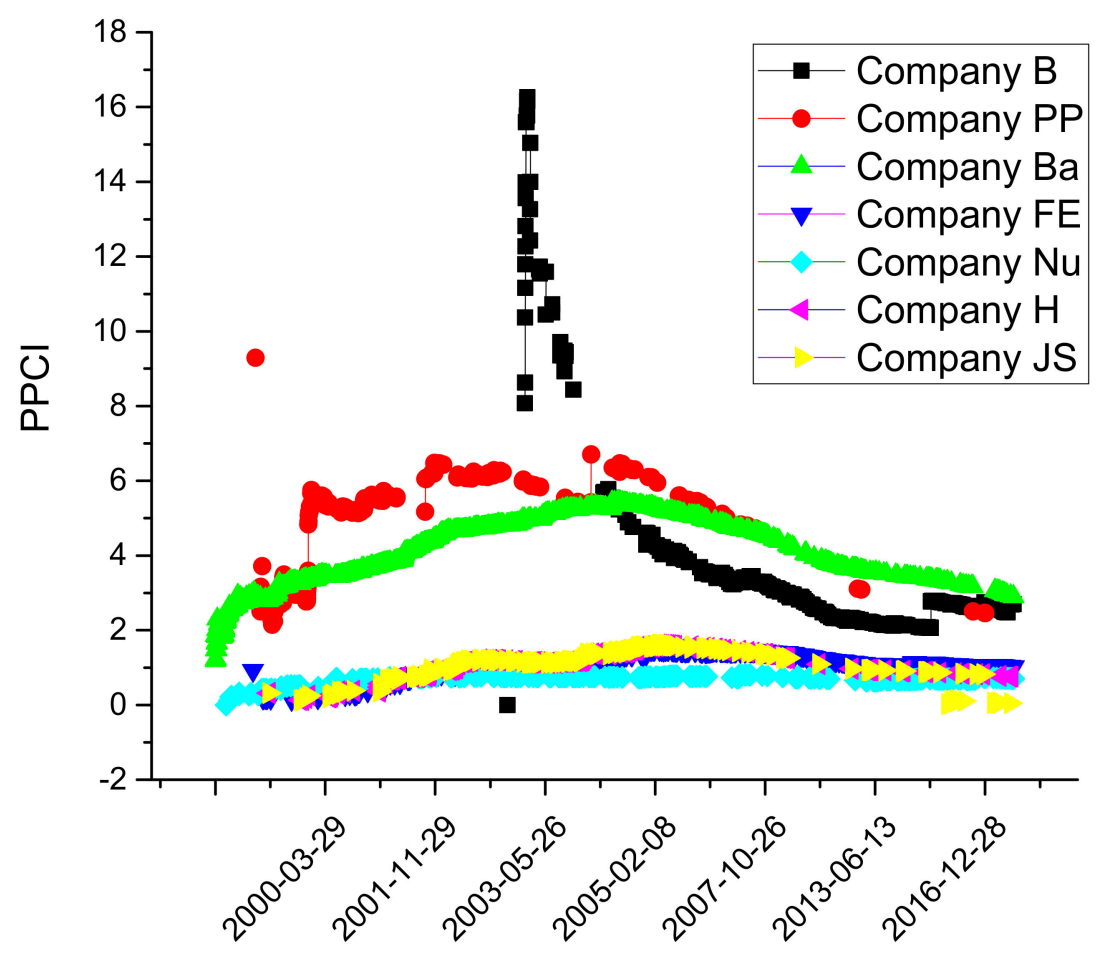

Figure 7. PPCI comparison of study case and six business competitors.

As presented in Figure 7, the PPCI of Company B is greater than those of the competitors. The PPCI is a measure in which the company's age is set as the denominator to eliminate comparative differences caused by company age differences. The PPCI comparison indicates that the patent value of Company $\mathrm{B}$ is higher than that of the competitors, representing a quantitative method of the proposed ladder.

\subsection{Ladder Framework for Commercialization of a Unicorn Start-up}

In summary, this study establishes five key ladder steps for the commercialization of a unicorn start-up. Figure 8 shows the ladder framework for commercialization of a unicorn start-up. 


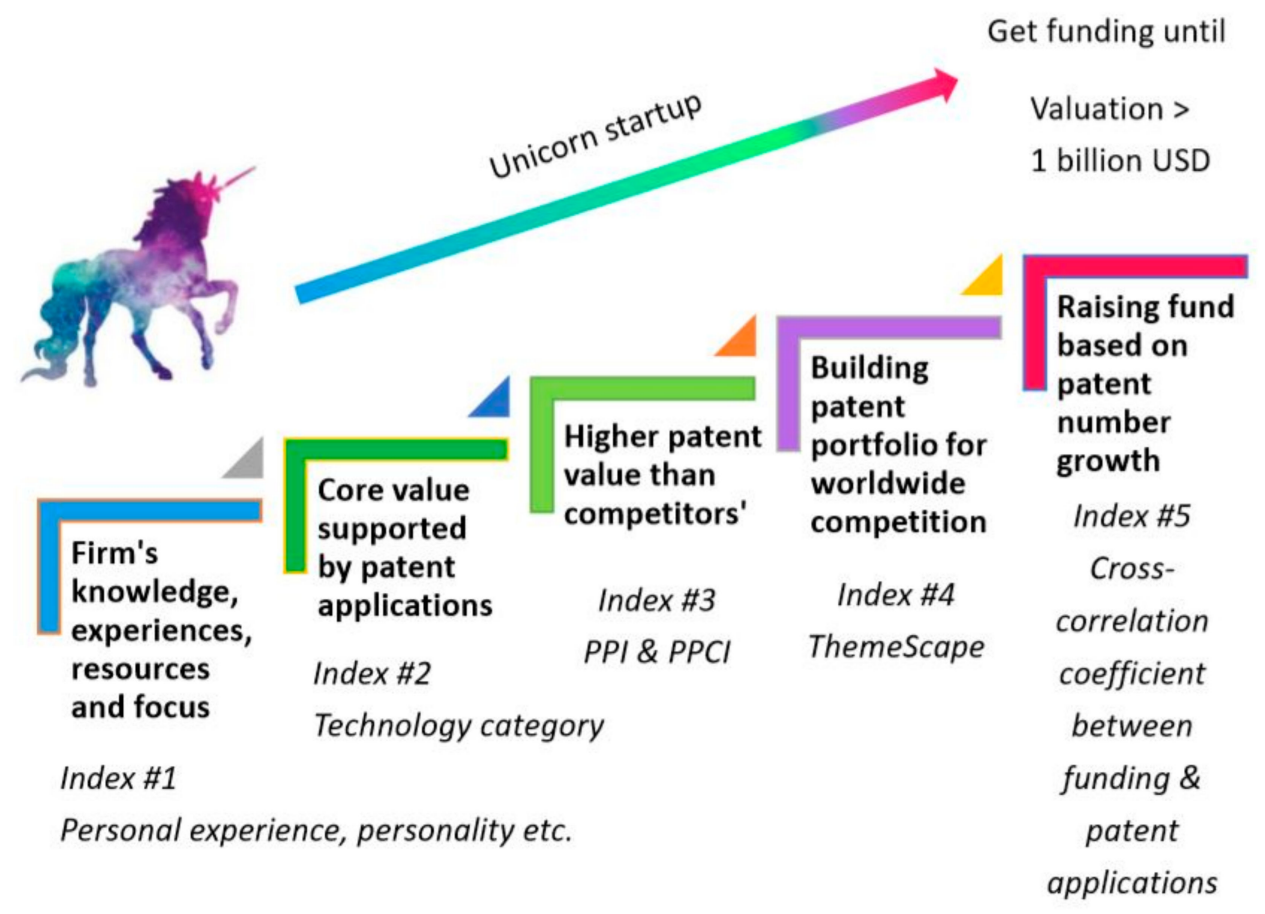

Figure 8. Ladder framework for commercialization of a unicorn start-up, which is prominent in SET development.

Performing ladder framework to incubate a unicorn start-up, the following observation indices are proposed in this study as listed below:

\subsubsection{Index \#1. Personal Experience}

At the beginning stage, founder team should have SETs-related experiences. It is better to have research and development experiences at a well-known research institute. That can help start-up company to grasp academic research results, save the cost of product development and avoid the waste of failed research and development. As discussed in a previous section, considerable researches on SOFCs have been published during the developing period of the study case, and academic data are beneficial to the commercialization. That is the basis of growth up to a unicorn start-up.

\subsubsection{Index \#2. Technology Category}

Initial business should have the core value. According to IP-based commercialization strategies, this value must be supported by IP. Key patent applications are crucial. As illustrated in Table 3, study case has $77.7 \%$ patent applications which were directly related to the company's core commercial values. The result reveals that applying for patents to create core commercial value is the second step to achieve business wins at the next stage.

\subsubsection{Index \#3. PPI and PPCI}

Business wins need higher product value than competitors producing similar products. According to IP-based commercialization strategies applied in this study, high product values depend on high value of patent applications. Two indices, PPI and PPCI, are developed by this study. As shown in Figure 7 , these indices do help to monitor patent value in a quantitative way during the developing stage of a start-up company. It is noted that Company B has much higher patent value than other competitors from 2002 to 2004 . That is the speculative reason why the study case can become a unicorn start-up. 


\subsubsection{Index \#4. ThemeScape}

To become a unicorn start-up, not only is there competition from similar-scale competitors but it also faces worldwide competitions, especially the competition from international business groups. In this study, the competitor to the study case is a large commercial group from Japan. It holds numerous fuel cell-related IP rights. The only way to beat a huge opponent is to find out the gap. In this study, a mapping tool-ThemeScape was proposed as an index to find out the openings in the patent landscape. As shown in Figures 5 and 6, this study can effectively compare the case company with an international competitor which owns the most fuel cell-related patents. By using ThemeScape, the study case found out the openings in the landscape and a patent portfolio was established. Thus, ThemeScape is proposed for incubating start-ups to have the ability for worldwide competitions. This thematic map tool is crucial for a unicorn start-up.

\subsubsection{Index \#5. Cross-correlation Coefficient between Funding and Patent Applications}

The study computes the number of patent applications filed and amount of funding received by existing 391 unicorn start-ups. The results indicate that for start-ups with continual funding and successful IPOs, the curve for the number of patent applications and that for the amount of funding are highly correlated. Using the previous four steps, a strong patent portfolio can be built in a quantitative way. The final step simply asks the start-up company to raise funds according to accumulated patent applications. Till valuation exceeds US $\$ 1$ billion, a unicorn start-up will be created.

A five-step ladder framework is developed for the incubation of a unicorn start-up. Using the quantitative index-PPI and PPCI, valuation of IP can be monitored during the company developing stage. A mapping tool-ThemeScape is proposed to find out the openings in the patent landscape. That can help the start-up company to face worldwide competition. To achieve business development, unicorn start-ups utilize substantial patent protection measures to constantly seek capital investment. This research finds out the number of patent applications of unicorn start-ups increases with the amount of funding. The correlation coefficient exceeds 0.97 . The above results clearly illustrate well management of patent applications, and IP valuation is crucial for incubating a unicorn start-up. That is the managerial implication of the results of this research.

From an academic point of view, it is a beginning, and even might be the first research to find out the way for widespread adoption of RETs and SETs by incubating a unicorn start-up. That makes technology development able to contribute to sustainable development.

\subsection{Study Limitations}

The ladder framework shown in Figure 8 can incubate a unicorn start-up by a quantitative way. However, SETs actually differ greatly in nature, use and developing phases, and thus have distinct challenges. This study is an attempt to identify key factors in becoming a unicorn start-up and to present a holistic view of a framework. Henceforth, the findings may not be applicable to one specific SET or RET. An in-depth study shall be conducted for each of the SETs and RETs in order to explore the factors affecting their commercialization process. An analysis protocol that can be used to model this methodological approach is expected in the next stage. Moreover, the current study has been conducted by only one study case. That is due to the rarity of the unicorn start-up in the energy field. Now, we only get one sample at worldwide from the 1960s till now. Therefore, the findings of the study may not be generalizable in a broader context.

\section{Conclusions}

This study integrates technology review, case study, and worldwide patent statistics to construct a ladder framework for incubation of a unicorn start-up which is prominent in SET development. Specifically, it analyzes key factors to explain how a company producing solid oxide fuel cells could 
transform into a unicorn start-up. Although there are some limitations, this study provides a reference for effectively transforming RETs and SETs into a high-valuation unicorn start-up.

The ladder framework consists of five steps including the check of a firm's knowledge, experiences, resources and focus; core value supported by patent applications; higher patent value than competitors; to build patent portfolio for worldwide competition and to raise funds based on patent number growth. With respect to each step, five different indices include personal experience, technology category, PPI and PPCI, ThemeScape and cross-correlation coefficient are suggested to incubate and monitor a start-up company. Using the quantitative index-PPI and PPCI developed in this study, valuation of IP can be monitored during a company's developing stage. In addition, a mapping tool-ThemeScape was proposed as an index to find out the openings in the patent landscape. That can help the start-up company to face and win worldwide competition. In this study, 399,310 patents associated with fuel cells at worldwide were visualized. Using the map, the openings in the landscape can be found to establish a patent portfolio for worldwide competition. Finally, the start-up company can raise funds according to accumulated patent applications with cross-correlation coefficient exceeding 0.97 . When valuation exceeds US $\$ 1$ billion, a unicorn start-up will be created.

In recent years, the global environment has deteriorated. Developments of SETs and RETs aim to save the worsening environment. However, research and development cannot really make any difference. Commercialization of RETs and SETs is the only way to produce possible results. In this study, we developed a quantitative methodology to incubate a unicorn start-up. That enables an effective and fast method for widespread adoption of RETs and SETs. We hope results obtained in this study can really contribute to sustainable development.

Supplementary Materials: The following are available online at http://www.mdpi.com/2071-1050/12/7/3018/s1.

Author Contributions: Substantial contribution to conception and design: D.L. Substantial contribution to acquisition of data: K.-C.L. Substantial contribution to analysis and interpretation of data: D.L. Drafting the article: D.L. and K.-C.L. Critically revising the article for important intellectual content: D.L. and K.-C.L. Final approval of the version to be published: D.L. All authors have read and agreed to the published version of the manuscript.

Acknowledgments: This research was partially funded by the "IMPACT" of the Ministry of Education, Taiwan, R.O.C. under Grant no. 209E02. The APC is borne by authors.

Conflicts of Interest: The authors declare that they have no known competing financial interests or personal relationships that could have appeared to influence the work reported in this paper.

$\begin{array}{ll}\text { Abbreviations } \\ \text { AFC } & \text { Alkaline Fuel Cell } \\ \text { DI } & \text { Derwent Innovation } \\ \text { DMFC } & \text { Direct Methane Fuel Cell } \\ \text { DOE } & \text { Department of Energy } \\ \text { FC } & \text { Fuel Cell } \\ \text { IEL } & \text { IEEE/IET Library } \\ \text { IP } & \text { Intellectual Property } \\ \text { IPO } & \text { Initial Public Offering } \\ \text { MCFC } & \text { Molten Carbonate Fuel Cell } \\ \text { PAFC } & \text { Phosphoric Acid Fuel Cell } \\ \text { PEMFC } & \text { Proton Exchange Membrane Fuel Cell } \\ \text { PPCI } & \text { Patent Portfolio Competition Index } \\ \text { PPI } & \text { Patent Power Index } \\ \text { R\&D } & \text { Research and Development } \\ \text { RET } & \text { Renewable Energy Technology } \\ \text { SDOL } & \text { Science Direction On Line } \\ \text { SET } & \text { Sustainable Energy Technology } \\ \text { SOFC } & \text { Solid Oxide Fuel Cell }\end{array}$




\section{References}

1. Available online: https://en.wikipedia.org/wiki/Commercialisation (accessed on 22 October 2019).

2. Balachandra, P.; Kristle Nathan, H.S.; Reddy, B.S. Commercialisation of sustainable energy technologies. Renew. Energy 2010, 35, 1842-1851. [CrossRef]

3. Shakeel, S.R.; Takala, J.; Zhu, L.D. Commercialisation of renewable energy technologies: A ladder building approach. Renew. Sustain. Energy Rev. 2017, 78, 855-867. [CrossRef]

4. Symeonidou, N.; Bruneel, J.; Autio, E. Commercialisation strategy and internationalization outcomes in technology-based new ventures. J. Bus. Ventur. 2017, 32, 302-317. [CrossRef]

5. Available online: https://www.cbinsights.com/ (accessed on 31 October 2019).

6. Available online: https://en.wikipedia.org/wiki/Fuel_cell (accessed on 23 October 2019).

7. Brown, J.T. Solid oxide fuel cell technology. IEEE Trans. Energy Convers. 1988, 3, 193-198. [CrossRef]

8. Stann, I. Fuel cells are coming to town. Power Eng. J. 1992, 6, 107. [CrossRef]

9. Hirschenhofer, J.H. Fuel Cell Status. IEEE Aerosp. Electron. Syst. Mag. 1994. [CrossRef]

10. Hirschenhofer, J.H. Fuel Cell Status: 1996. IEEE Aerosp. Electron. Syst. Mag. 1997, 12, 23-28. [CrossRef]

11. T-Raissi, A.; Banerjee, A.; Sheinkopf, K.G. Current Technology of Fuel Cell Systems. In Proceedings of the Thirty-Second Intersociety Energy Conversion Engineering Conference (Cat. No. 97CH6203), Honolulu, HI, USA, 27 July-1 August 1997; pp. 1953-1957.

12. Singhal, S.C. Advances in solid oxide fuel cell technology. Solid State Ionics 2000, 135, 305-313. [CrossRef]

13. Zhu, W.Z.; Deevi, S.C. A review on the status of anode materials for solid oxide fuel cells. Mater. Sci. Eng. A 2003, 362, 228-239. [CrossRef]

14. Shri Prakash, B.; Senthil Kumar, S.; Aruna, S.T. Properties and development of Ni/YSZ as an anode material in solid oxide fuel cell: A review. Renew. Sustain. Energy Rev. 2014, 36, 149-179. [CrossRef]

15. Shaikh, S.P.S.; Muchtar, A.; Somalu, M.R. A review on the selection of anode materials for solid-oxide fuel cells. Renew. Sustain. Energy Rev. 2015, 51, 1-8. [CrossRef]

16. Mahato, N.; Banerjee, A.; Gupta, A.; Omar, S.; Balani, K. Progress in material selection for solid oxide fuel cell technology: A review. Prog. Mater. Sci. 2015, 72, 141-337. [CrossRef]

17. Da Silva, F.S.; De Souza, T.M. Novel materials for solid oxide fuel cell technologies: A literature review. Int. J. Hydrogen Energy 2017, 42, 26020-26036. [CrossRef]

18. Fergus, J.W. Sealants for solid oxide fuel cells. J. Power Sources 2005, 147, 46-57. [CrossRef]

19. Pederson, L.R.; Singh, P.; Zhou, X.D. Application of vacuum deposition methods to solid oxide fuel cells. Vacuum 2006, 80, 1066-1083. [CrossRef]

20. Yano, M.; Tomita, A.; Sano, M.; Hibino, T. Recent advances in single-chamber solid oxide fuel cells: A review. Solid State Ionics 2007, 177, 3351-3359. [CrossRef]

21. Kakaç, S.; Pramuanjaroenkij, A.; Zhou, X.Y. A review of numerical modeling of solid oxide fuel cells. Int. J. Hydrogen Energy 2007, 32, 761-786. [CrossRef]

22. Wang, K.; Hissel, D.; Péra, M.C.; Steiner, N.; Marra, D.; Sorrentino, M.; Pianese, C.; Monteverde, M.; Cardone, P.; Saarinen, J. A Review on solid oxide fuel cell models. Int. J. Hydrogen Energy 2011, 36, 7212-7228. [CrossRef]

23. Hajimolana, S.A.; Hussain, M.A.; Daud, W.M.A.W.; Soroush, M.; Shamiri, A. Mathematical modeling of solid oxide fuel cells: A review. Renew. Sustain. Energy Rev. 2011, 15, 1893-1917. [CrossRef]

24. Laguna-Bercero, M.A. Recent advances in high temperature electrolysis using solid oxide fuel cells: A review. J. Power Sources 2012, 203, 4-16. [CrossRef]

25. Lee, M.; Park, G.; Radisavljevic-Gajic, V. Modeling of solid oxide fuel cells (SOFCs): An overview. In Proceedings of the 2013 5th International Conference on Modeling, Simulation and Applied Optimization (ICMSAO), Hammamet, Tunisia, 28-30 April 2013; pp. 1-6.

26. Peksen, M. Numerical thermomechanical modelling of solid oxide fuel cells. Prog. Energy Combust. Sci. 2015, 48, 1-20. [CrossRef]

27. Sun, C.; Stimming, U. Recent anode advances in solid oxide fuel cells. J. Power Sources 2007, 171, $247-260$. [CrossRef]

28. Riipinen, T.; Väisänen, V.; Kuisma, M.; Seppä, L.; Mustonen, P.; Silventoinen, P. Requirements for power electronics in solid oxide fuel cell system. In Proceedings of the 2008 13th International Power Electronics and Motion Control Conference, Poznan, Poland, 1-3 September 2008; pp. 1233-1238. 
29. Kirubakaran, A.; Nema, R.K.; Jain, S.K. Distributed generation by solid oxide fuel cell: A review. In Proceedings of the 2008 Joint International Conference on Power System Technology POWERCON and IEEE Power India Conference, New Delhi, India, 12-15 October 2008; pp. 1-7.

30. Choudhury, A.; Chandra, H.; Arora, A. Application of solid oxide fuel cell technology for power generation-A review. Renew. Sustain. Energy Rev. 2013, 20,430-442. [CrossRef]

31. Nayak, S.K.; Gaonkar, D.N. Fuel cell based hybrid distributed generation systems, "a review". In Proceedings of the 2013 IEEE 8th International Conference on Industrial and Information Systems (ICIIS 2013), Kandy, Sri Lanka, 17-20 December 2013; pp. 525-530.

32. Pramuanjaroenkij, A.; Kakaç, S.; Yang Zhou, X. Mathematical analysis of planar solid oxide fuel cells. Int. J. Hydrogen Energy 2008, 33, 2547-2565. [CrossRef]

33. Aruna, S.T.; Balaji, L.S.; Kumar, S.S.; Prakash, B.S. Electrospinning in solid oxide fuel cells-A review. Renew. Sustain. Energy Rev. 2017, 67, 673-682. [CrossRef]

34. Evans, A.; Bieberle-Hütter, A.; Rupp, J.L.M.; Gauckler, L.J. Review on microfabricated micro-solid oxide fuel cell membranes. J. Power Sources 2009, 194, 119-129. [CrossRef]

35. Gorte, R.J.; Vohs, J.M. Nanostructured anodes for solid oxide fuel cells. Curr. Opin. Colloid Interface Sci. 2009, 14, 236-244. [CrossRef]

36. Zhang, X.; Chan, S.H.; Li, G.; Ho, H.K.; Li, J.; Feng, Z. A review of integration strategies for solid oxide fuel cells. J. Power Sources 2010, 195, 685-702. [CrossRef]

37. Tucker, M.C. Progress in metal-supported solid oxide fuel cells: A review. J. Power Sources 2010, 195, 4570-4582. [CrossRef]

38. Gómez, S.Y.; Hotza, D. Current developments in reversible solid oxide fuel cells. Renew. Sustain. Energy Rev. 2016, 61, 155-174. [CrossRef]

39. Huang, K.; Singhal, S.C. Cathode-supported tubular solid oxide fuel cell technology: A critical review. J. Power Sources 2013, 237, 84-97. [CrossRef]

40. Leung, M.; Park, G.; Radisavljevic-Gajic, V. Control of solid oxide fuel cells: An overview. In Proceedings of the 2013 9th Asian Control Conference (ASCC 2013), Istanbul, Turkey, 23-26 June 2013; pp. 1-6.

41. He, W.; Zou, J.; Wang, B.; Vilayurganapathy, S.; Zhou, M.; Lin, X.; Zhang, K.H.L.; Lin, J.; Xu, P.; Dickerson, J.H. Gas transport in porous electrodes of solid oxide fuel cells: A review on diffusion and diffusivity measurement. J. Power Sources 2013, 237, 64-73. [CrossRef]

42. Jiang, S.P.; Chen, X. Chromium deposition and poisoning of cathodes of solid oxide fuel cells-A review. Int. J. Hydrogen Energy 2014, 39, 505-531. [CrossRef]

43. Liu, M.; Aravind, P.V. The fate of tars under solid oxide fuel cell conditions: A review. Appl. Therm. Eng. 2014, 70, 687-693. [CrossRef]

44. Afif, A.; Radenahmad, N.; Cheok, Q.; Shams, S.; Kim, J.H.; Azad, A.K. Ammonia-fed fuel cells: A comprehensive review. Renew. Sustain. Energy Rev. 2016, 60, 822-835. [CrossRef]

45. Available online: https://en.wikipedia.org/wiki/Bloom_Energy_Server (accessed on 20 August 2019).

46. Van Biert, L.; Godjevac, M.; Visser, K.; Aravind, P.V. A review of fuel cell systems for maritime applications. J. Power Sources 2016, 327, 345-364. [CrossRef]

47. Dekel, D.R. Review of cell performance in anion exchange membrane fuel cells. J. Power Sources 2018, 375 , 158-169. [CrossRef]

48. Arsalis, A. A comprehensive review of fuel cell-based micro-combined-heat-and-power systems. Renew. Sustain. Energy Rev. 2019, 105, 391-414. [CrossRef]

49. Yue, M.; Jemei, S.; Gouriveau, R. ScienceDirect Review on health-conscious energy management strategies for fuel cell hybrid electric vehicles: Degradation models and strategies. Int. J. Hydrogen Energy 2019, 44, 6844-6861. [CrossRef]

50. Chen, H.; Zhao, X.; Zhang, T.; Pei, P. The reactant starvation of the proton exchange membrane fuel cells for vehicular applications: A review. Energy Convers. Manag. 2019, 182, 282-298. [CrossRef]

51. Shabani, B.; Hafttananian, M.; Khamani, S.; Ramiar, A.; Ranjbar, A.A. Poisoning of proton exchange membrane fuel cells by contaminants and impurities: Review of mechanisms, effects, and mitigation strategies. J. Power Sources 2019, 427, 21-48. [CrossRef]

52. Mahdi, E.; Bouziane, K.; Zamel, N.; François, X. Effects of mechanical compression on the performance of polymer electrolyte fuel cells and analysis through in-situ characterisation techniques-A review. J. Power Sources 2019, 424, 8-26. 
53. Mohmed, A.; Jiang, F. ScienceDirect Stresses and their impacts on proton exchange membrane fuel cells: A review. Int. J. Hydrogen Energy 2017, 43, 2327-2348.

54. Chang, Y.; Qin, Y.; Yin, Y.; Zhang, J.; Li, X. Humidification strategy for polymer electrolyte membrane fuel cells-A review. Appl. Energy 2018, 230, 643-662. [CrossRef]

55. Xing, L.; Shi, W.; Su, H.; Xu, Q.; Das, P.K.; Mao, B.; Scott, K. Membrane electrode assemblies for PEM fuel cells: A review of functional graded design and optimization. Energy 2019, 177, 445-464. [CrossRef]

56. Inci, M. Review of fuel cells to grid interface: Configurations, technical challenges and trends. J. Clean. Prod. 2019, 213, 1353-1370. [CrossRef]

57. Arshad, A.; Jabbal, M.; Yan, Y.; Habib, A.; Bashir, M.A. Energy and exergy analysis of fuel cells: A review. Therm. Sci. Eng. Prog. 2019, 9, 308-321. [CrossRef]

58. Yu, J.; Lee, C. Effect of Cell Size on the Performance and Fuel Cells. Energies 2020. [CrossRef]

59. Cell, M.F. Comparative Study on the Effects of Three Membrane. Energies 2020. [CrossRef]

60. Gurau, V.; De Castro, E.S. Prediction of Performance Variation Caused by Manufacturing Tolerances and Defects in Gas Diffusion Electrodes of Phosphoric Acid (PA)-Doped Proton Exchange Membrane Fuel Cells. Energies 2020. [CrossRef]

61. Manoharan, Y.; Hosseini, S.E.; Butler, B.; Alzhahrani, H. Applied sciences Hydrogen Fuel Cell Vehicles; Current Status and Future Prospect. Appl. Sci. 2019, 9, 2296. [CrossRef]

62. Available online: https://en.wikipedia.org/wiki/Bloom_Energy (accessed on 31 October 2019).

63. Available online: https://en.wikipedia.org/wiki/Toyota (accessed on 22 October 2019).

64. Available online: https://www.owler.com/company/plugpower (accessed on 23 October 2019).

65. Available online: https://en.wikipedia.org/wiki/Ballard_Power_Systems (accessed on 24 October 2019).

66. Available online: https://www.owler.com/company/fuelcellenergy (accessed on 20 October 2019).

67. Available online: https://www.owler.com/company/nuvera (accessed on 24 October 2019).

68. Available online: https://www.owler.com/company/hydrogenics (accessed on 31 October 2019).

69. Available online: https://www.owler.com/company/joiscientifico (accessed on 23 October 2019).

70. Available online: https://en.wikipedia.org/wiki/Magic_Leap (accessed on 29 October 2019).

71. Available online: https://en.wikipedia.org/wiki/Jawbone (accessed on 31 October 2019).

72. Available online: https://www.yitutech.com/en (accessed on 31 October 2019).

(C) 2020 by the authors. Licensee MDPI, Basel, Switzerland. This article is an open access article distributed under the terms and conditions of the Creative Commons Attribution (CC BY) license (http://creativecommons.org/licenses/by/4.0/). 